\title{
The spring 2011 final stratospheric warming above Eureka: anomalous dynamics and chemistry
}

C. Adams ${ }^{1, *}$, K. Strong ${ }^{1}$, X. Zhao ${ }^{1}$, A. E. Bourassa ${ }^{2}$, W. H. Daffer ${ }^{3}$, D. Degenstein ${ }^{2}$, J. R. Drummond ${ }^{1,4}$ E. E. Farahani ${ }^{1}$, A. Fraser ${ }^{1, *}$, N. D. Lloyd ${ }^{2}$, G. L. Manney ${ }^{3, * *}, 5$, C. A. McLinden ${ }^{6}$, M. Rex ${ }^{7}$, C. Roth ${ }^{2}$, S. E. Strahan ${ }^{8}$, K. A. Walker ${ }^{1,9}$, and I. Wohltmann ${ }^{7}$

${ }^{1}$ Department of Physics, University of Toronto, Toronto, Canada

${ }^{2}$ University of Saskatchewan, Saskatoon, Saskatchewan, Canada

${ }^{3}$ Jet Propulsion Laboratory, California Institute of Technology, Pasadena, USA

${ }^{4}$ Department of Physics and Atmospheric Sciences, Dalhousie University, Halifax, Canada

${ }^{5}$ New Mexico Institute of Mining and Technology, Socorro, New Mexico, USA

${ }^{6}$ Environment Canada, Downsview, Ontario, Canada

${ }^{7}$ Alfred Wegener Institute for Polar and Marine Research, Potsdam, Germany

${ }^{8}$ Universities Space Research Association, Columbia, Maryland, USA

${ }^{9}$ Department of Chemistry, University of Waterloo, Waterloo, Canada

*now at: Institute for Space and Atmospheric Studies, University of Saskatchewan, Saskatoon, Canada

*** now at: School of GeoSciences, University of Edinburgh, Edinburgh, UK

*** now at: NorthWest Research Associates, Socorro, New Mexico, USA

Correspondence to: C. Adams (cristen.adams@usask.ca)

Received: 16 May 2012 - Published in Atmos. Chem. Phys. Discuss.: 10 August 2012

Revised: 3 January 2013 - Accepted: 6 January 2013 - Published: 17 January 2013

\begin{abstract}
In spring 2011, the Arctic polar vortex was stronger than in any other year on record. As the polar vortex started to break up in April, ozone and $\mathrm{NO}_{2}$ columns were measured with UV-visible spectrometers above the Polar Environment Atmospheric Research Laboratory (PEARL) in Eureka, Canada $\left(80.05^{\circ} \mathrm{N}, 86.42^{\circ} \mathrm{W}\right)$ using the differential optical absorption spectroscopy (DOAS) technique. These ground-based column measurements were complemented by Ozone Monitoring Instrument (OMI) and Optical Spectrograph and Infra-Red Imager System (OSIRIS) satellite measurements, Global Modeling Initiative (GMI) simulations, and meteorological quantities. On 8 April 2011, $\mathrm{NO}_{2}$ columns above PEARL from the DOAS, OMI, and GMI datasets were approximately twice as large as in previous years. On this day, temperatures and ozone volume mixing ratios above Eureka were high, suggesting enhanced chemical production of $\mathrm{NO}_{2}$ from NO. Additionally, GMI $\mathrm{NO}_{\mathrm{x}}\left(\mathrm{NO}+\mathrm{NO}_{2}\right)$ and $\mathrm{N}_{2} \mathrm{O}$ fields suggest that downward transport along the vortex edge and horizontal transport from lower latitudes also contributed to the enhanced $\mathrm{NO}_{2}$.
\end{abstract}

The anticyclone that transported lower-latitude $\mathrm{NO}_{\mathrm{x}}$ above PEARL became frozen-in and persisted in dynamical and GMI $\mathrm{N}_{2} \mathrm{O}$ fields until the end of the measurement period on 31 May 2011. Ozone isolated within this frozen-in anticyclone (FrIAC) in the middle stratosphere was lost due to reactions with the enhanced $\mathrm{NO}_{\mathrm{x}}$. Below the FrIAC (from the tropopause to $700 \mathrm{~K}$ ), $\mathrm{NO}_{\mathrm{x}}$ driven ozone loss above $\mathrm{Eu}$ reka was larger than in previous years, according to GMI monthly average ozone loss rates. Using the passive tracer technique, with passive ozone profiles from the Lagrangian Chemistry and Transport Model, ATLAS, ozone losses since 1 December 2010 were calculated at $600 \mathrm{~K}$. In the air mass that was above Eureka on 20 May 2011, ozone losses reached 4.2 parts per million by volume (ppmv) (58\%) and $4.4 \mathrm{ppmv}$ (61\%), when calculated using GMI and OSIRIS ozone profiles, respectively. This gas-phase ozone loss led to a more rapid decrease in ozone column amounts above Eureka in April/May 2011 compared with previous years. Groundbased, OMI, and GMI ozone total columns all decreased by more than $100 \mathrm{DU}$ from 15 April to 20 May. Two lows in the 
ozone columns were also investigated and were attributed to a vortex remnant passing above Eureka at $\sim 500 \mathrm{~K}$ on $12 / 13$ May and an ozone mini-hole on 22/23 May.

\section{Introduction}

During the spring-time break-up of the Arctic polar vortex, large variability in stratospheric trace gases can be observed as vortex and lower-latitude air masses mix. Fragments of the polar vortex, containing characteristic values of chemical tracers, such as low $\mathrm{N}_{2} \mathrm{O}$, can become "frozen-in" and be advected throughout the hemisphere (e.g., Hess, 1991). Similarly, lower-latitude air masses, containing, e.g., enhanced $\mathrm{N}_{2} \mathrm{O}$, can be transported northward. In some cases, these low-latitude air masses remain intact through the summer. These so-called frozen-in anticyclones (FrIACs) were observed in 2003 (Lahoz et al., 2007), 2005 (Manney et al., 2006; Allen et al., 2011), and 2007 (Thieblemont et al., 2011). The 2005 FrIAC formed during the final stratospheric warming and persisted until late May in dynamical fields, and until late summer in chemical tracer fields measured by the Microwave Limb Sounder (MLS) satellite instrument (Manney et al., 2006). These features were also captured by the Global Modeling Initiative (GMI) chemistry transport model (CTM) (Allen et al., 2011).

Ozone volume mixing ratios (VMRs) within frozen-in features depend primarily on middle stratosphere chemistry, as the air masses are isolated. Photochemical production through odd-oxygen reactions depends primarily on solar zenith angle (SZA), while catalytic loss depends primarily on $\mathrm{NO}_{\mathrm{x}}$ concentrations and SZA. For large SZA (limited sunlight), both the photochemical production and catalytic destruction of ozone are slow. However, production drops off more rapidly with SZA than does destruction. This leads to a maximum ozone loss rate for SZA 80-95 (Sinnhuber et al., 1999).

In the winter, low-ozone pockets have been observed inside anticyclones shortly after the peak of a stratospheric warming (Manney et al., 1995a; Harvey et al., 2002, 2004, 2008). Low-ozone pockets form because the anticyclone isolates the air mass from ozone-rich lower-latitude air and sunlight is limited, repressing the photochemical production of ozone (Morris et al., 1998; Nair et al., 1998). Low-ozone pockets tend to have 5-30\% less ozone than surrounding ambient air (Harvey et al., 2008). In the summer, lower ozone has also been noted inside anticyclones, but is typically attributed to dynamics instead of chemistry (Orsolini et al., 2003; Orsolini and Nikulin, 2006). Overall, summertime ozone loss is driven by 24-h sunlight, as $\mathrm{NO}_{\mathrm{x}}$ is released from its night-time reservoirs, leading to a $\sim 30 \%$ decrease in the ozone column (e.g., Farman et al., 1985; Perliski et al., 1989; Fahey and Ravishankara, 1999).
Spring-time polar ozone loss is typically associated with heterogeneous chemistry in the lower stratosphere. However, Konopka et al. (2007) found that $\mathrm{NO}_{\mathrm{x}}$-driven middle stratosphere ozone loss during stratospheric warmings can have a greater impact than halogens for some Arctic springs. They studied the transport of subtropical ozone and $\mathrm{NO}_{\mathrm{x}}$-rich air to the Arctic in spring 2003, a year in which the Arctic lower stratosphere was warm. By late April 2003, local ozone loss was up to $50 \%$ at the $600-\mathrm{K}$ potential temperature level and was dominated by $\mathrm{NO}_{\mathrm{x}}$ chemistry, which accounted for $76 \%$ of the loss for the region between 600 and $900 \mathrm{~K}$. Therefore, the ozone loss rates were strongly dependent on the amount of $\mathrm{NO}_{\mathrm{y}}$ transported from lower latitudes.

In spring 2011, the Arctic polar vortex was stronger through February and March than in any other year on record (Manney et al., 2011). Because of persistently low temperatures, continuous depletion via heterogeneous chemistry was observed until 20 April, leading to record ozone loss (Balis et al., 2011; Manney et al., 2011). These findings have been investigated with differential optical absorption spectroscopy (DOAS), Fourier transform infrared spectrometer, radiosonde, and lidar measurements taken at the Polar Environment Atmospheric Research Laboratory (PEARL) in Eureka, Canada $\left(80.05^{\circ} \mathrm{N}, 86.42^{\circ} \mathrm{W}\right)$ by the Canadian Network for the Detection of Atmospheric Change (CANDAC) (Adams et al., 2012b; Lindenmaier et al., 2012).

In early April 2011, DOAS $\mathrm{NO}_{2}$ columns above PEARL reached approximately twice the column amount observed during the same season in previous years (Adams et al., $2012 b$ ). Therefore, we present an investigation of groundbased, satellite, and model $\mathrm{NO}_{2}$ and ozone data above PEARL in April/May 2011. $\mathrm{N}_{2} \mathrm{O}$ and aerosol are used as dynamical tracers, with low $\mathrm{N}_{2} \mathrm{O}$ and aerosol indicating vortex air masses and high $\mathrm{N}_{2} \mathrm{O}$ and aerosol indicating lowerlatitude air masses (e.g., Ruth et al., 1994; Harvey et al., 1999). The ground-based, satellite, and model datasets used in this study are described in Sect. 2. The evolution of these datasets above Eureka in the context of previous years is presented in Sect. 3.1. The relative roles of chemistry and transport in the large increase in the $\mathrm{NO}_{2}$ column are discussed in Sect. 3.2. The subsequent development and evolution of a FrIAC, and middle-stratosphere gas-phase ozone loss is investigated in Sect. 3.3. In Sect. 3.4 a vortex fragment and an ozone mini-hole over Eureka are illustrated. Conclusions are given in Sect. 4.

\section{Datasets}

For this study, ground-based, satellite, and model datasets were combined in order to produce a complete picture of the vortex break-up in 2011 above Eureka. Ground-based DOAS measurements were used to identify unusual variations in ozone and $\mathrm{NO}_{2}$ columns above Eureka. Ozone and $\mathrm{NO}_{2}$ profiles were then resolved using Optical Spectrograph 
and Infra-Red Imager System (OSIRIS) satellite measurements. OSIRIS aerosol measurements were also used to identify vortex and lower-latitude air masses. Ozone Monitoring Instrument (OMI) satellite ozone and $\mathrm{NO}_{2}$ column measurements complemented these datasets, in particular in early April, when OSIRIS was turned off for annual maintenance. The evolution of ozone and $\mathrm{NO}_{2}$ was investigated using meteorological fields from Derived Meteorological Products (DMPs) and modeled ozone, $\mathrm{NO}_{2}$, and $\mathrm{N}_{2} \mathrm{O}$ from the GMI CTM. Since passive ozone was not available from the GMI runs used in this study, ATLAS passive ozone was used to quantify $\mathrm{NO}_{\mathrm{x}}$-driven ozone loss during these events. These datasets are described in the sections below.

\subsection{DOAS ozone and $\mathrm{NO}_{2}$}

Ozone and $\mathrm{NO}_{2}$ columns were measured above PEARL by two UV-visible DOAS instruments: the PEARL and University of Toronto ground-based spectrometers (GBSs) (Fraser et al., 2009). Measurements were taken at PEARL (prior to 2005, the Arctic Stratospheric Ozone Observatory - AStrO), which has been operated by CANDAC since 2005. Measurements included in this study were acquired during CANDAC routine operations (August 2006 to present), the Stratospheric Indicators of Climate Change Campaign (spring 2003) and the Canadian Arctic ACE Validation Campaigns (springs 2004-2011) (Kerzenmacher et al., 2005; Fraser et al., 2008). The GBSs are part of the Network for the Detection of Atmospheric Composition Change (NDACC) and their Eureka ozone and $\mathrm{NO}_{2}$ datasets are described in detail by Adams et al. (2012a). Measurements from the two GBS instruments are nearly identical and therefore were combined into a single GBS dataset.

The GBSs are UV-visible Triax-180 triple-grating spectrometers, built by Instruments S.A./Jobin Yvon Horiba, with cooled charge-coupled device detectors and a $2^{\circ}$ field-ofview. The resolution of the GBSs varies from $0.2-2.5 \mathrm{~nm}$ depending on the selected grating and wavelength range. The GBSs recorded spectra in April and/or May at Eureka in 1999, 2003, 2004 and 2007-2011. Only data from 20042011 are used in the present study for consistency with GMI and OMI.

Ozone and $\mathrm{NO}_{2}$ differential slant column densities (DSCDs) were retrieved using the DOAS technique with the QDOAS software (Fayt et al., 2011). Ozone DSCDs were analyzed using the NDACC recommendations published in Hendrick et al. (2011) in the 450-545 nm and 450-540 nm fitting windows for the UT-GBS and PEARL-GBS, respectively. The following cross-sections were all fit during the DOAS procedure: ozone measured at $223 \mathrm{~K}$ (Bogumil et al., 2003), $\mathrm{NO}_{2}$ measured at $220 \mathrm{~K}$ (Vandaele et al., 1998), $\mathrm{H}_{2} \mathrm{O}$ (converted from line parameters given in Rothman et al., 2003), wavelength-corrected $\mathrm{O}_{4}$ (Greenblatt et al., 1990), and the Ring pseudoabsorber (Chance and Spurr, 1997), which accounts for the filling in of absorption lines due to
Raman scattering. An additional cross-section was applied to correct for systematic polarization errors in the analysis. $\mathrm{NO}_{2}$ was retrieved in two different wavelength regions: 425 $450 \mathrm{~nm}$ (GBS-vis) and 350-380 nm (GBS-UV), depending on the selected grating. The $\mathrm{NO}_{2}$-vis DSCDs were retrieved using the same cross-sections as ozone, with the addition of a first-order offset correction to account for stray light. Polarization correction cross-sections were not necessary for $\mathrm{NO}_{2}$, perhaps due to the shorter wavelength region of the analysis. For $\mathrm{NO}_{2}$-UV, a $\mathrm{BrO}$ cross-section measured at $223 \mathrm{~K}$ (Fleischmann et al., 2004) and an OClO cross-section measured at $204 \mathrm{~K}$ (Wahner et al., 1987) were also included in the analysis.

Ozone and $\mathrm{NO}_{2}$ vertical columns were retrieved from DSCDs using the Langley method in the SZA $86-91^{\circ}$ range, or the nearest available SZA, with air mass factor look-up tables provided by the Belgian Institute for Space Aeronomy (IASB-BIRA). The ozone air mass factors produce total columns (Hendrick et al., 2011), while the $\mathrm{NO}_{2}$ air mass factors produce partial columns from $17 \mathrm{~km}$ to the top of the atmosphere (Appendix A of Adams et al., 2012a). On average, errors of $6.0 \%$ for ozone, $19 \%$ for $\mathrm{NO}_{2}$-vis and $19 \%$ for $\mathrm{NO}_{2}$-UV were calculated for April/May GBS measurements. The mean relative differences for OSIRIS minus GBS columns in the Arctic are $5.7 \%$ for ozone, $-7.3 \%$ for GBSvis $\mathrm{NO}_{2}$, and $-3.3 \%$ for GBS-UV (Adams et al., 2012a).

\subsection{OSIRIS ozone, $\mathrm{NO}_{2}$, and aerosol}

The OSIRIS satellite instrument was launched aboard the Odin spacecraft in February 2001 (Murtagh et al., 2002; Llewellyn et al., 2004). It observes limb-radiance profiles with a $1-\mathrm{km}$ vertical field-of-view over altitudes ranging from approximately $10-100 \mathrm{~km}$, with coverage from $82.2^{\circ} \mathrm{N}$ to $82.2^{\circ} \mathrm{S}$. The grating Optical Spectrograph measures scattered sunlight from $280-800 \mathrm{~nm}$, with 1-nm spectral resolution. The OSIRIS $25-\mathrm{km}$ tangent height is within $500 \mathrm{~km}$ of Eureka $\sim 5-10$ times per day and measurements of ozone, aerosol, and $\mathrm{NO}_{2}$ are taken during the sunlit part of the year (from approximately 1 March to 15 October above Eureka).

The SaskMART Multiplicative Algebraic Reconstruction Technique (Degenstein et al., 2009) v5.0x (v5.0.1 and v5.0.6) ozone and aerosol were used in this study. Ozone absorption information in both the UV and visible parts of the spectrum is used to retrieve number density profiles from $60 \mathrm{~km}$ to the cloud tops (down to a minimum of $10 \mathrm{~km}$ in the absence of clouds). OSIRIS ozone VMRs, calculated using OSIRIS number density profiles and European Centre for MediumRange Forecasts (EMWF) neutral density profiles, are also available. SaskMART v5.0x ozone profiles agree with those from SAGE II (Stratospheric Aerosol and Gas Experiment) to within $2 \%$ from $18-53 \mathrm{~km}$ (Degenstein et al., 2009). Systematic and other errors are expected to be on the same order as the instrument noise. SaskMART aerosol extinction at $750 \mathrm{~nm}$ (Bourassa et al., 2007) is retrieved with an assumed 
height profile and a single-mode log-normal particle size distribution. OSIRIS aerosol agrees with SAGE II and SAGE III measurements to within $15 \%$ for the lower stratosphere (Bourassa et al., 2012).

For $\mathrm{NO}_{2}$, the v3.0 Optimal Estimation data product was used. $\mathrm{NO}_{2}$ slant column densities (SCDs) are retrieved using the DOAS technique in the $435-451 \mathrm{~nm}$ range. These SCDs are converted to number density profiles from $10-46 \mathrm{~km}$ using an optimal estimation inversion, with high response for 15-42 km (Brohede et al., 2008). OSIRIS $\mathrm{NO}_{2}$ VMRs, calculated from ECMWF number density and OSIRIS neutral density profiles, are also available. The precision of these measurements is $16 \%$ between $15-25 \mathrm{~km}$ and $6 \%$ between $25-35 \mathrm{~km}$ based on comparisons with other instruments (OSIRIS, 2011).

To investigate air masses above Eureka, OSIRIS ozone, aerosol, and $\mathrm{NO}_{2}$ profiles were averaged daily within $500 \mathrm{~km}$ of Eureka. To produce polar maps at fixed potential temperature levels, data were passed through a Gaussian filter with a $5^{\circ}$ standard deviation onto a $5 \times 5^{\circ}$ grid. For each grid-point, the angular distance between the grid-point and the OSIRIS measurements was calculated. Weights based on the angular distance between the measurements and the grid-point were calculated using a Gaussian function, with a standard deviation of $5^{\circ}$. The weighted mean of OSIRIS measurements at the given grid-point was then calculated. If the sum of weights at a given grid-point was $<1$, the grid-point was left empty. The filter and interpolation grid were tested for various cases to ensure that smoothing and interpolation were not introducing any spurious features to the maps. The $5^{\circ}$ filter provided the best balance between showing the detail in the OSIRIS measurements, without introducing large gaps in the figure. The choice of interpolation grid did not have a significant impact on the maps for the measurement dates considered.

\subsection{OMI ozone and $\mathrm{NO}_{2}$}

On board the Earth Observing System Aura satellite, OMI (Levelt et al., 2006) measures sunlight backscattered from the Earth's surface at UV and visible wavelengths. OMI takes measurements in the sunlit part of the globe, with a nadir resolution that varies from $13 \times 24 \mathrm{~km}^{2}$ to $24 \times 48 \mathrm{~km}^{2}$ and daily global coverage.

For the present study, OMIDOAO3 ozone total columns were used. OMIDOAS3 ozone columns are retrieved using an algorithm that is based on the DOAS technique (Veefkind et al., 2006; Veefkind and Sneep, 2009). Fits are performed in a 5-nm-wide fitting window, centred at $334.1 \mathrm{~nm}$. AMFs are determined using a radiative transfer model. OMDOAO3 total columns have been validated extensively against other instruments and have been shown to agree typically within $2 \%$ or better, with a slight SZA dependence at high latitudes (e.g., McPeters et al., 2008 and references therein). Hendrick et al. (2011) found that OMIDOAO3 columns agreed with high-latitude ground-based DOAS measurements to within $\sim 5 \%$.

The Dutch OMI $\mathrm{NO}_{2}$ retrieval (DOMINO) stratospheric $\mathrm{NO}_{2}$ product was used in this study (Boersma et al., 2007, 2011; Dirksen et al., 2011). $\mathrm{NO}_{2}$ SCDs are retrieved using the DOAS technique in the $405-465 \mathrm{~nm}$ range. SCDs are then assimilated in a CTM and stratospheric partial columns are produced. DOMINO stratospheric $\mathrm{NO}_{2}$ agrees with ground-based measurements to within $0.3 \times 10^{15} \mathrm{~mol} \mathrm{~cm}^{-2}$ (13\%) (Dirksen et al., 2011).

To investigate air masses above Eureka, daily OMI ozone and $\mathrm{NO}_{2}$ columns within $500 \mathrm{~km}$ of Eureka were averaged. To produce polar maps at fixed potential temperature levels, data were passed through a Gaussian filter with a standard deviation of $1^{\circ}$ and interpolated onto $1^{\circ} \times 1^{\circ}$ horizontal grid, using the method described in Sect. 2.2. Note that a smaller grid and standard deviation were used for OMI than for OSIRIS because OMI has better horizontal resolution.

\subsection{Derived Meteorological Products}

Meteorological quantities were obtained from DMPs (Manney et al., 2007) that were calculated daily at 12:00 UTC directly above PEARL using the GEOS Version 5.1.0 and 5.2.0 (GEOS-5) analyses (Reinecker, 2008). DMP temperatures, scaled potential vorticity (sPV, potential vorticity scaled in "vorticity units" to give a similar range of values at each level, e.g., Dunkerton and Delisi, 1986; Manney et al., 1994) and equivalent latitude (EqL, the latitude that would enclose the same area as a given PV contour, e.g., Butchart and Remsberg, 1986) were all considered in this study. sPV values of $1.6 \times 10^{-4} \mathrm{~s}^{-1}$ and $1.2 \times 10^{-4} \mathrm{~s}^{-1}$ are used to define the inner and outer vortex edges, respectively (Manney et al., 2007). Manney et al. (2007) and Lindenmaier et al. (2012) have shown that using a single sPV value to define the vortex edge throughout the fall/winter/spring season gives comparable results to other commonly used vortex edge identification methods. EqL provides a coordinate system that separates air masses inside and outside the polar vortex.

\subsection{GMI}

In order to interpret satellite measurements, GMI a 3-D CTM (Strahan et al., 2007) with full chemistry in the troposphere and stratosphere (Duncan et al., 2007) was used. The GMI CTM is integrated with meteorological fields from the GEOS-5.2.0 Modern Era Retrospective-analysis for Research and Applications (MERRA) (Rienecker et al., 2011). The GMI chemical formulation includes 125 species, with 322 thermal chemical reactions, 82 photolysis reactions, including heterogeneous reactions on aerosols and polar stratospheric clouds. Time-varying natural and anthropogenic emissions are included. Tropospheric processes represented in the simulation include convection, wet scavenging, dry deposition, and $\mathrm{NO}_{\mathrm{x}}$ produced from lightning (Allen et al., 
2010). The GMI-MERRA simulation is integrated at $2^{\circ} \times$ $2.5^{\circ}$ (latitude $\times$ longitude) on 72 pressure levels, ranging from the surface to $0.015 \mathrm{hPa}$. For this study, daily ozone, $\mathrm{NO}_{2}$, and $\mathrm{NO}$ fields used are averaged for 10:00-11:00 LT, in order to sample $\mathrm{NO}$ and $\mathrm{NO}_{2}$ at the same part of the diurnal cycle throughout the Northern Hemisphere (e.g., at a fixed LT). $\mathrm{N}_{2} \mathrm{O}$ was not available in the GMI 10:00-11:00 LT model output. Therefore, $\mathrm{N}_{2} \mathrm{O}, \mathrm{PV}$, and temperature are model "snapshots" from the daily 12:00 UTC model output. Profiles were interpolated to the latitude and longitude of Eureka. Polar maps at various potential temperature levels were also produced.

\subsection{ATLAS passive ozone}

Passive ozone was calculated using the Lagrangian Chemistry and Transport Model ATLAS (Wohltmann and Rex, 2009; Wohltmann et al., 2010). Ozone was treated as a passive dynamical tracer with no chemistry. The passive tracer was initialized on 1 December 2010, using profiles from MLS. Meteorological data from the ECMWF ERA-Interim reanalysis are used to drive the model (Dee et al., 2011). The model resolution is approximately $150 \mathrm{~km}$ in the horizontal and $1-2 \mathrm{~km}$ in the vertical. The model uses a hybrid vertical coordinate (pressure/potential temperature), which is to a good approximation a potential temperature coordinate. Heating rates from the ERA-Interim reanalysis drive the vertical motion. Transport and mixing in ATLAS passive ozone has been validated against other models and datasets and was found to be in good agreement (Wohltmann and Rex, 2009).

\section{Results}

\subsection{The springtime stratosphere above Eureka in 2011}

Figure 1 shows the timeseries of $\mathrm{NO}_{2}$ and ozone columns above Eureka from GBS ground-based measurements (top), OMI satellite overpasses (middle), and GMI model output (bottom). The 2004-2010 data is shown in grey and the 2011 data in red. Good agreement is observed between the three datasets. In years prior to 2011, $\mathrm{NO}_{2}$ columns increase during April and May as hours of sunlight at Eureka increase (SZAs decrease). This is expected as $\mathrm{NO}_{\mathrm{x}}$ is released from night-time reservoirs through photochemical reactions. Note that only qualitative agreement is expected, as the seasonal increase in $\mathrm{NO}_{2}$ depends on the SZA at which $\mathrm{NO}_{2}$ is sampled. Ozone columns decrease throughout the spring, as descent in the polar vortex ceases and ozone is lost through gasphase cycles. In 2011, $\mathrm{NO}_{2}$ and ozone columns are low on 4 April, when the polar vortex briefly passes above Eureka. On 8 April (labeled $\mathrm{A}$ ), $\mathrm{NO}_{2}$ increases to values that are nearly two times larger than in previous years in all three datasets. This is attributed to $\mathrm{NO}_{\mathrm{x}}$ transport and the chemical production of $\mathrm{NO}_{2}$ in Sect. 3.2. Throughout the rest of April/May, $\mathrm{NO}_{2}$ columns gradually return to values that are compara-
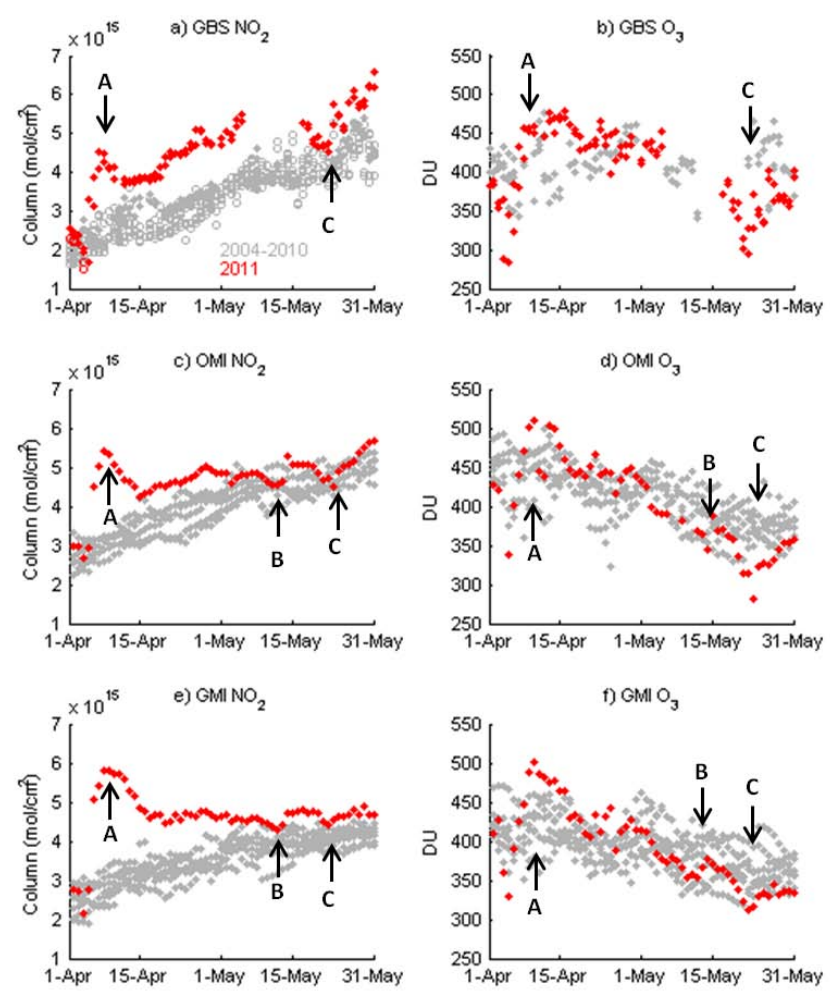

Fig. 1. Timeseries of $\mathrm{NO}_{2}$ columns $\left(\mathrm{mol} \mathrm{cm}^{-2}\right)$ and ozone columns (DU) above Eureka for 1 April to 31 May in 2011 (red) and in 2004-2011 (grey). (a) GBS-vis (closed circles) and GBS-UV (open circles) $\mathrm{NO}_{2}$ partial columns (17 km to top of atmosphere) and (b) GBS ozone total columns, both measured both in morning and evening twilights. (c) OMI stratospheric $\mathrm{NO}_{2}$ columns and (d) OMI total ozone columns averaged daily within $500 \mathrm{~km}$ of Eureka. (e) $\mathrm{NO}_{2}$ and (f) ozone total columns from daily GMI output from 10:00-10:30 a.m. local time at Eureka. Note that there are fewer ozone than $\mathrm{NO}_{2}$ GBS measurements because, for some years, spring-time dedicated $\mathrm{BrO}$ measurements excluded the visible wavelengths used to measure ozone. Black arrows labelled A, B, C indicate 8 April, 13 May, and 22 May, respectively.

ble to previous years. Ozone total columns also increase in early April, reaching maxima between $\sim 10-15$ April. They then decrease throughout the rest of April/May, at a faster rate than in previous years, due to enhanced homogeneous $\mathrm{NO}_{\mathrm{x}}$ chemistry, some of which occurs within a FrIAC, as discussed in Sect. 3.3. Ozone columns above Eureka also decrease on 12/13 May (labeled B) due to a vortex fragment at $500 \mathrm{~K}$, and on the $22 / 23$ May (labeled C) due to an ozone mini-hole, as described in Sect. 3.4.

Profiles of meteorological quantities, trace gases, and aerosol extinction are shown in Fig.. 2 for 2011 (red lines) and 2004-2010 (grey lines). Average profiles for 2011 (blue dashed lines) and 2004-2010 (thick black lines) are also shown. Note that approximate altitudes corresponding to the potential temperature levels are given on the right $\mathrm{y}$-axis of panel a. Temperatures above Eureka (panel a) in 2011 
reached the highest values in the record from 400 to $1000 \mathrm{~K}$. Average April/May 2011 temperatures are also higher than average temperatures in previous years for $400-1400 \mathrm{~K}$. EqLs (panel b) in 2011 are smaller than observed in all of the previous years $\left(<30^{\circ} \mathrm{N}\right.$ between $700 \mathrm{~K}$ and $1400 \mathrm{~K}$, and at $\sim 450 \mathrm{~K}$ ) suggesting the transport of lower-latitude air above Eureka. A minimum equivalent latitude of $19^{\circ}$ was observed at $850 \mathrm{~K}$ on 16 April. Therefore, the warm temperatures are likely due to the poleward advection of warm tropical air over Eureka. OSIRIS $\mathrm{NO}_{2}$ VMRs (panel c) are enhanced in 2011 for $500-1400 \mathrm{~K}$, which is consistent with the large $\mathrm{NO}_{2}$ column amounts (Fig. 1a, c, e). OSIRIS ozone VMRs (panel d) in 2011 are on average smaller than in previous years for potential temperature levels below $1300 \mathrm{~K}$. OSIRIS aerosol extinction (panel e) and GMI $\mathrm{N}_{2} \mathrm{O}$ VMRs (panel f) are larger in 2011 than previous years above $\sim 650 \mathrm{~K}$, suggesting enhanced transport of lower-latitude air over Eureka. Average GMI $\mathrm{NO}_{\mathrm{x}}\left(\mathrm{NO}+\mathrm{NO}_{2}\right)$ (panel g) is larger in 2011 than previous years for potential temperature levels $>500 \mathrm{~K}$. For potential temperature levels $>700 \mathrm{~K}$, many of the April/May $2011 \mathrm{NO}_{\mathrm{x}}$ profiles are larger than in any other year.

Figure 3 shows the evolution of temperature (panel a) and EqL (panel b) above Eureka during April and May of 2011. The white contour lines indicate $\mathrm{sPV}=1.6 \times 10^{-4}$ $\mathrm{s}^{-1}$, which can be used to approximate the inner vortex edge. Air masses within these contour lines are considered to be inside the polar vortex. Select $\mathrm{N}_{2} \mathrm{O}$ contours (black) are overlaid above the EqL. On 4 April, the vortex is above Eureka from 550 to $1450 \mathrm{~K}$. Above $600 \mathrm{~K}$, the vortex is displaced from Eureka on 5 April. Between 4 and 6 April, temperatures rise rapidly (from 226 to $246 \mathrm{~K}$ at the $850-\mathrm{K}$ potential temperature level) and $\mathrm{EqL}$ decreases sharply (from $81^{\circ}$ to $40^{\circ}$ at the $850-\mathrm{K}$ potential temperature level). This suggests that the high temperatures are due to the rapid poleward transport of lower-latitude air. Low EqL (values $<30^{\circ}$ ) and enhanced $\mathrm{N}_{2} \mathrm{O}$ indicate tropical air for $\sim 10-20$ April between $\sim 700$ $1100 \mathrm{~K}$. The altitude range of low EqL narrows with time. During May, as SZAs decrease and more sunlight enters the atmosphere, temperatures gradually increase. At altitudes below $600 \mathrm{~K}$, the vortex gradually moves away from Eureka until 13 April. Following 13 April, there are intervals of high and low EqL (coinciding with low and high $\mathrm{N}_{2} \mathrm{O}$ ), suggesting that vortex and lower-latitude air are moving above Eureka.

GMI NO 2 , with $\mathrm{NO}_{\mathrm{x}}$ contours overlaid (black lines) (panel c) and GMI ozone (panel d) are also shown in Fig. 3. Note that GMI data is shown because OSIRIS did not take measurements in early April. During the period of overlap, good agreement between OSIRIS and GMI is observed. As the vortex moves away from Eureka, $\mathrm{NO}_{2}$ VMRs increase and correspond to high temperatures (panel a) and large ozone VMRs (panel d). The enhanced $\mathrm{NO}_{2}$ VMRs are further investigated in Sect. 3.2. Reduced ozone VMRs approximately follow low EqLs (panel b) from 15 April to 31 May. This is discussed further in Sect. 3.3.
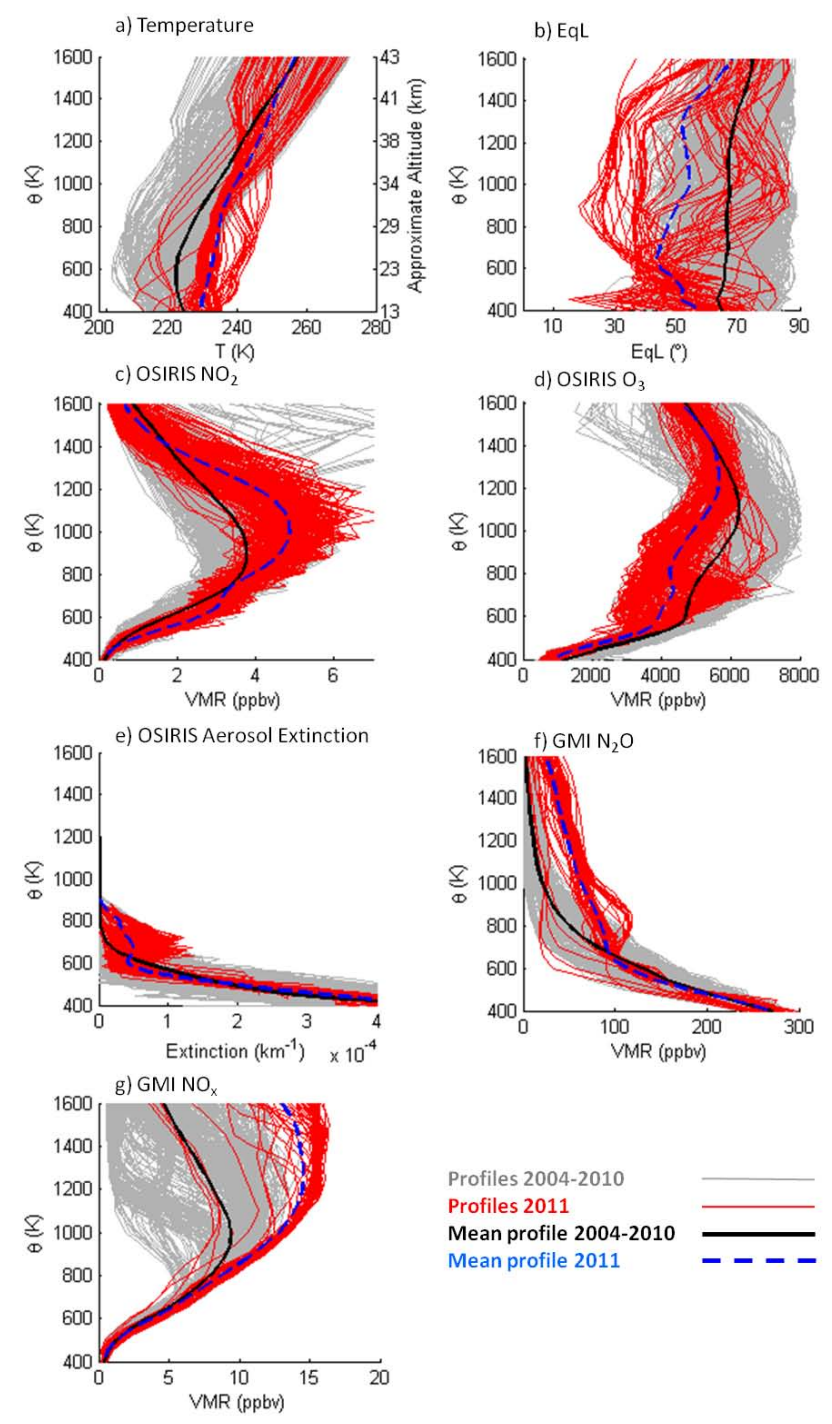

Profiles 2004-2010 Profiles 2011 Mean profile 2004-2010 Mean profile 2011

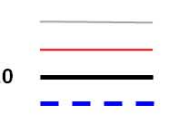

Fig. 2. Profiles of meteorological fields and composition above PEARL for 1 April to 31 May. Thin grey and thick black lines indicate individual profiles and average profiles, respectively for 20042010. Thin red lines and thick blue dashed lines indicate individual profiles and average profiles, respectively for 2011. (a) Temperature (K) and (b) EqL $\left(^{\circ}\right)$ from GEOS-5 DMPs at 12:00 UTC above Eureka. (c) $\mathrm{NO}_{2} \mathrm{VMR}$ (parts per billion by volume - ppbv), (d) ozone VMR (ppbv), and (e) aerosol extinction $\left(\mathrm{km}^{-1}\right)$ from OSIRIS measurements within $500 \mathrm{~km}$ of Eureka. (f) $\mathrm{N}_{2} \mathrm{O}$ VMR (ppbv) and (g) $\mathrm{NO}_{\mathrm{x}}$ VMR (ppbv) from GMI daily profiles above Eureka. The approximate altitude corresponding to the potential temperature levels is shown in the y-axis of (a).

\section{2 $\mathrm{NO}_{2}$ maximum on 8 April}

A large maximum was observed in the $\mathrm{NO}_{2}$ column (Fig. 1a, c, e, event A) and profile timeseries (Fig. 2c) on 8 April 2011. The chemical production of $\mathrm{NO}_{2}$ from $\mathrm{NO}_{\mathrm{x}}$ is favoured for high temperatures and large ozone VMRs (e.g., Sander et al., 2011). Above Eureka, enhanced $\mathrm{NO}_{2}$ on 8 April corresponds 


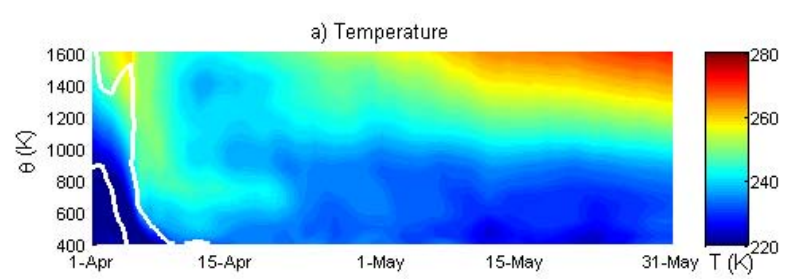

b) $\mathrm{EqL}$ and $\mathrm{GMIN} \mathrm{N}_{2} \mathrm{O}$

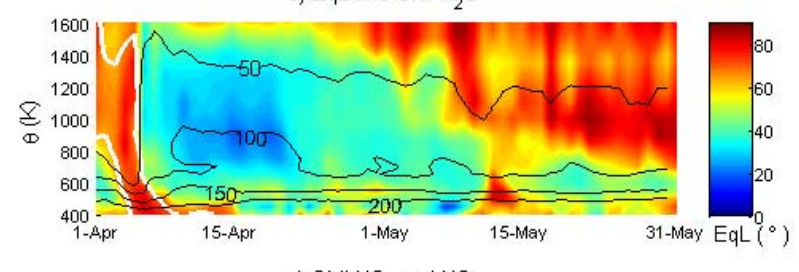

c) $\mathrm{GMINO}_{2}$ and $\mathrm{NO}_{x}$
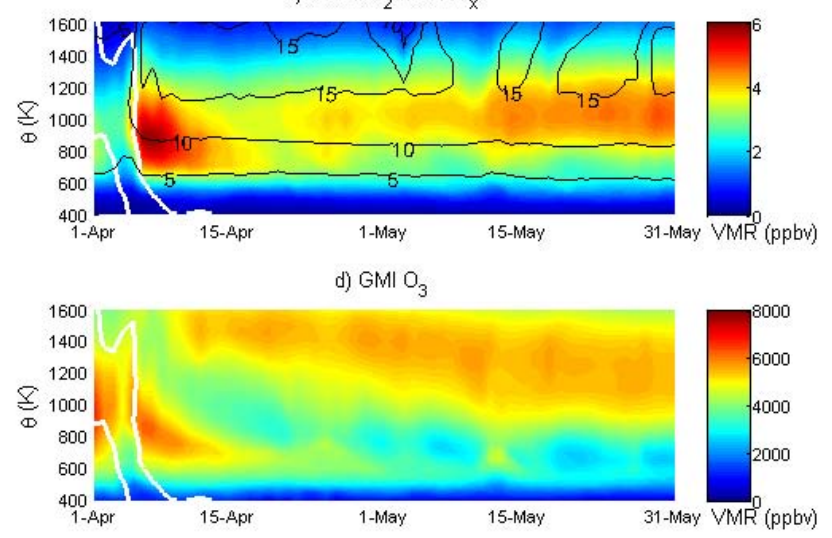

Fig. 3. Time-potential temperature plots above Eureka for April/May 2011. (a) Temperature (K) from GEOS-5 DMPs. (b) EqL $\left({ }^{\circ}\right)$ (color-scale) from GEOS-5 DMPs and $\mathrm{N}_{2} \mathrm{O}$ VMR (black contour lines, with labels given in ppbv) from GMI. (c) $\mathrm{NO}_{2} \mathrm{VMR}$ (color-scale in ppbv) and $\mathrm{NO}_{\mathrm{x}}$ VMR (black contour lines, with labels given in ppbv) from GMI. (d) Ozone VMR (ppbv) from GMI. Low [high] temperatures, EqLs, and VMRs are given in blue [red]. Thick white lines indicate boundaries of the polar vortex determined by $\mathrm{sPV}=1.6 \times 10^{-4} \mathrm{~s}^{-1}$.

to large ozone VMRs and high temperatures for potential temperature levels $>600 \mathrm{~K}$ (Fig. 3), suggesting the chemical production of $\mathrm{NO}_{2}$ from $\mathrm{NO}$. Additionally, $\mathrm{NO}_{\mathrm{x}}$ increases as the vortex moves away, suggesting that transport also plays a role (Fig. 3c, black contours). This section describes the synoptic evolution of the transport and chemical production of $\mathrm{NO}_{2}$ from 1-8 April.

Figure 4 shows polar maps of OMI ozone total columns and $\mathrm{NO}_{2}$ stratospheric partial columns for 1,3,5, and 8 April 2011. $\mathrm{sPV}=1.6 \times 10^{-4} \mathrm{~s}^{-1}$ contours, which approximately enclose the polar vortex, are also shown for three potential temperature levels. On 1 April, low ozone and $\mathrm{NO}_{2}$ columns reside over Siberia and Northern Europe, coinciding with the location of the polar vortex. On 3 and 5 April, low ozone and $\mathrm{NO}_{2}$ columns stretch toward Eureka as the polar vortex shifts and stretches overhead. By 8 April, the low $\mathrm{NO}_{2}$ columns

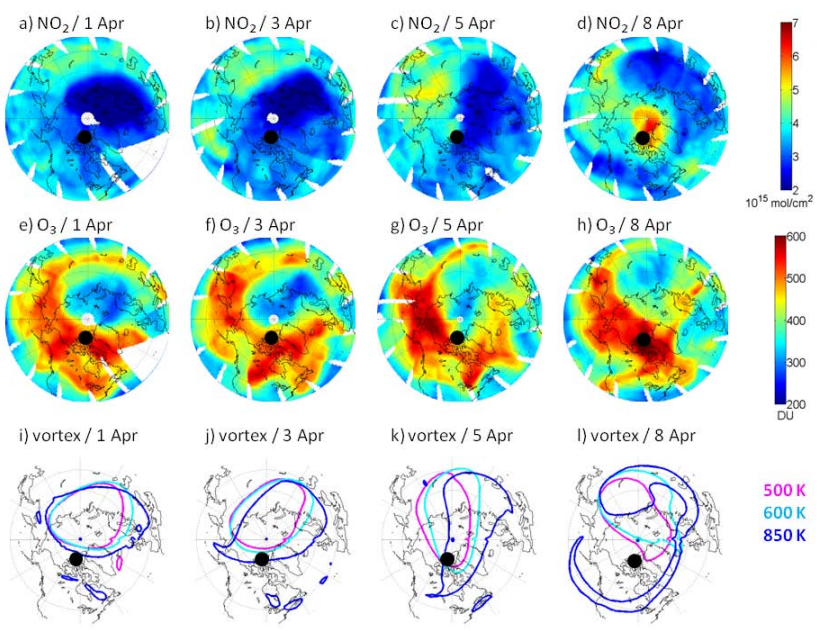

Fig. 4. Polar maps of $\mathrm{OMI} \mathrm{NO}_{2}$ stratospheric columns in mol cm $\mathrm{cm}^{-2}$ (top row), OMI ozone total columns in DU (middle row) and the approximate inner vortex edge (bottom row) for 1, 3, 5 and 8 April 2011. Small [large] column values are given in blue [red]. The inner vortex edge is approximated at $\mathrm{sPV}=1.6 \times 10^{-4} \mathrm{~s}^{-1}$ for $500-\mathrm{K}$ (magenta), 600-K (cyan), and 850-K (blue) potential temperature levels. Eureka is indicated by the black circle.

have stretched into a "C" shape, with Eureka and very high $\mathrm{NO}_{2}$ columns at its centre. The low in ozone remains across the pole from Eureka. Low $\mathrm{NO}_{2}$ columns coincide approximately with the location of the polar vortex in the middle stratosphere $(\sim 850 \mathrm{~K})$, while low ozone columns coincide with the lower stratosphere vortex $(\sim 500 \mathrm{~K})$. This is consistent with the differences between the altitudes of the ozone and $\mathrm{NO}_{2}$ number density maxima.

Polar maps of GMI $\mathrm{NO}_{2}$, ozone, $\mathrm{N}_{2} \mathrm{O}$, and $\mathrm{NO}_{\mathrm{x}}$ for 1,3 , 5, and 8 April at $600 \mathrm{~K}(\sim 23 \mathrm{~km})$ are shown in Fig. 5. This is the altitude of the $\mathrm{NO}_{2}$ number density maximum above Eureka in 2011 according to OSIRIS profiles and therefore yields the largest contribution to the $\mathrm{NO}_{2}$ columns. The polar vortex (bounded by the white PV contours), encloses low $\mathrm{NO}_{2}$, ozone, $\mathrm{N}_{2} \mathrm{O}$, and $\mathrm{NO}_{\mathrm{x}}$. At this level, the vortex moves over Eureka on 5 April as a pocket of warm air (enclosed by the purple contour line) appears between Alaska and Siberia. On 8 April, the pocket of warm air is situated directly above Eureka, the vortex has stretched away and $\mathrm{NO}_{2}$ is enhanced. The $\mathrm{NO}_{2} / \mathrm{NO}_{\mathrm{x}}$ ratio above Eureka at $600 \mathrm{~K}$ is $2.4-4.4$ times larger than in previous years on the same date. $\mathrm{NO}_{\mathrm{x}}$ VMRs above Eureka on 8 April 2011 at $600 \mathrm{~K}$ are comparable to previous years, but they are 1.5-2 times larger than surrounding airmasses (Fig. 5p). North of Eureka, $\mathrm{NO}_{\mathrm{x}}$-rich air is located along the vortex edge, where $\mathrm{N}_{2} \mathrm{O}$ is low, suggesting the downward transport of higher-altitude $\mathrm{NO}_{\mathrm{x}}$-rich and $\mathrm{N}_{2} \mathrm{O}$-poor air. Transported lower-latitude air, indicated by high $\mathrm{N}_{2} \mathrm{O}$, is located southwest of Eureka. This suggests that the $\mathrm{NO}_{\mathrm{x}}$-rich air that has been transported downward along the vortex edge was drawn over Eureka between the polar 


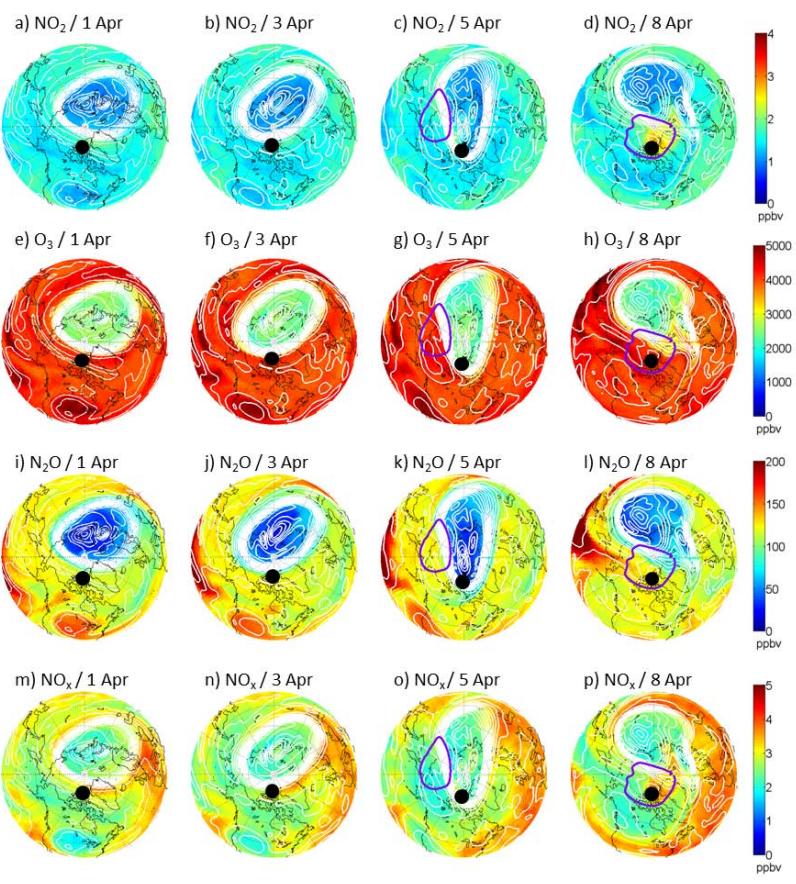

Fig. 5. Polar maps at the $600-\mathrm{K}(\sim 23-\mathrm{km})$ potential temperature of GMI $\mathrm{NO}_{2}$ (top row), ozone (top middle row), $\mathrm{N}_{2} \mathrm{O}$ (bottom middle row), and $\mathrm{NO}_{\mathrm{x}}$ (bottom row) VMRs given in ppbv for 1, 3, 5 and 8 April 2011. Low [high] VMRs are given in blue [red]. White lines indicate PV contours. The area enclosed by the purple contour indicates $T>235 \mathrm{~K}$. Eureka is indicated by the black circle.

vortex to the north and lower-latitude air to the south. Therefore, the high $\mathrm{NO}_{2}$ VMRs above Eureka at $600 \mathrm{~K}$ are due to both downward transport and chemical production.

Figure 6 shows polar maps of GMI $\mathrm{NO}_{2}$, ozone, $\mathrm{N}_{2} \mathrm{O}$ and $\mathrm{NO}_{\mathrm{x}}$ at $850 \mathrm{~K}(\sim 31 \mathrm{~km})$, the altitude of the large increase in GMI $\mathrm{NO}_{2}$ VMRs (Fig. 3d) and the altitude at which OMI $\mathrm{NO}_{2}$ columns appear to follow the shape of the polar vortex (Fig. 4). Low-latitude air, indicated by high $\mathrm{N}_{2} \mathrm{O}$, is transported from Northern Europe, wrapping counter-clockwise around the vortex. By 8 April, the vortex has shifted to a "C" shape, with high temperatures and $\mathrm{NO}_{2}$ at its center, directly above Eureka. At this altitude, the ratio of $\mathrm{NO}_{2} / \mathrm{NO}_{\mathrm{x}}$ above Eureka is 2.0-4.6 times larger in 2011 than on the same date in previous years. At this level, the $\mathrm{NO}_{2}$ increase is dominated by production from $\mathrm{NO}$, due to the high temperatures. Enhanced lower-latitude ozone is also transported poleward, and VMRs decrease as it reaches Eureka. This is discussed further in Sect. 3.3.

Above the $1000-\mathrm{K}$ potential temperature level, temperatures above Eureka are normal within the context of previous years, but $\mathrm{NO}_{\mathrm{x}}$ and $\mathrm{NO}_{2}$ are enhanced (Fig. 2a, c, g) and strong poleward transport of $\mathrm{NO}_{\mathrm{x}}$ is apparent in synoptic maps (not shown here). Therefore, at these altitudes, horizontal transport of $\mathrm{NO}_{\mathrm{x}}$ from lower latitudes also contributes to the enhanced $\mathrm{NO}_{2}$ columns.
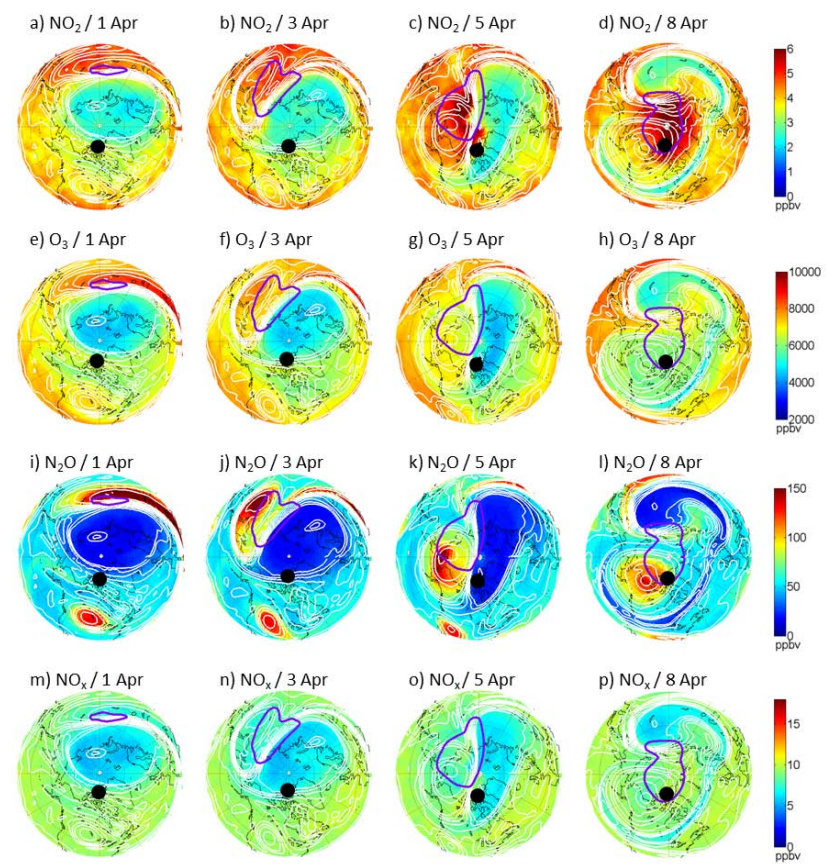

Fig. 6. As for Fig. 5 at the $850-\mathrm{K}(\sim 31-\mathrm{km})$ potential temperature level. The area enclosed by the purple contour indicates $T>245 \mathrm{~K}$. Note that color scales are different from Fig. 5.

\subsection{FrIAC and gas phase ozone loss}

In early April, lower-latitude air was transported above Eureka into an anticyclone. The early evolution of this anticyclone is evident in the GMI fields at $850 \mathrm{~K}$, shown in Fig. 6. Low-latitude air, identified by high $\mathrm{N}_{2} \mathrm{O}$ enclosed by PV contours, wraps counter-clockwise around the polar vortex. By 8 April, the edge of this air mass is above Eureka. Ozone VMRs inside the air mass on 1 April are enhanced, as is consistent with the transport of ozone-rich lower-latitude air. However, as the anticyclone moves over Eureka, the ozone VMRs within it decrease, suggesting chemical ozone loss. The anticyclone persists at $850 \mathrm{~K}$ in PV contours and high $\mathrm{N}_{2} \mathrm{O}$ throughout April and May, as shown in Fig. 7. OSIRIS and GMI ozone agree well, both showing filaments of highozone lower-latitude air being drawn around the anticyclone, and low ozone within the anticyclone. The anticyclone at $850 \mathrm{~K}$ remains centred above Eureka for 13-20 April and is then advected by easterly winds and begins to rotate around the pole, with the edge of the anticyclone remaining above Eureka. This feature persists until at least the end of May, suggesting a 2011 FrIAC.

The evolution of the FrIAC can be seen in Fig. 3b. EqLs (color scale) are low and $\mathrm{N}_{2} \mathrm{O}$ VMRs (black contours) are enhanced until $\sim 20$ April as the anticyclone remains above Eureka. Following the advection of the anticyclone, $\mathrm{N}_{2} \mathrm{O}$ maxima (and EqL minima) pass over Eureka on 1, 6, 21, and 29 May. Examination of $\mathrm{N}_{2} \mathrm{O}$ polar maps at $850 \mathrm{~K}$ and $1150 \mathrm{~K}$ 


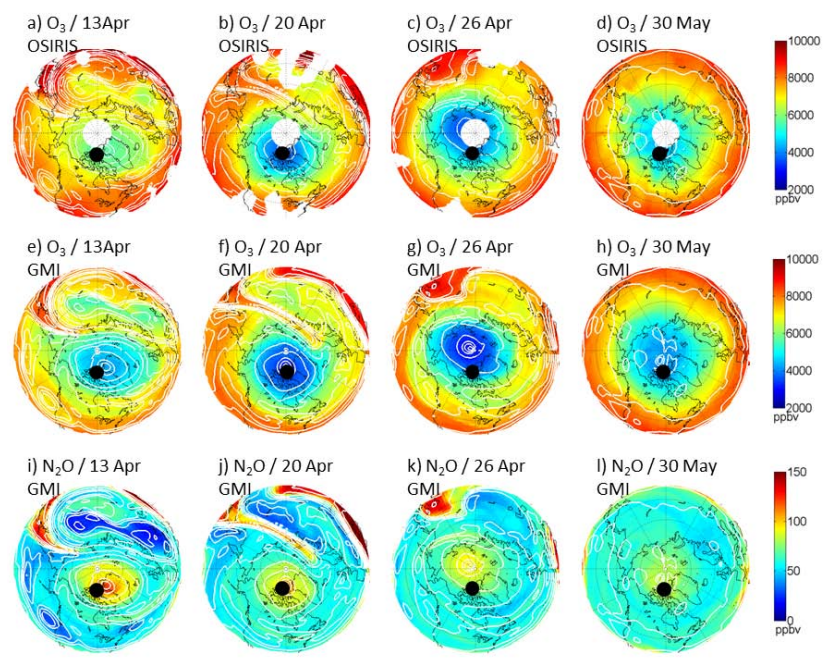

Fig. 7. Polar maps at the $850-\mathrm{K}$ potential temperature level of OSIRIS ozone (top row), GMI ozone (middle row), and GMI $\mathrm{N}_{2} \mathrm{O}$ (bottom row) VMRs given in ppbv for 13, 20, 26 April and 30 May 2011. Low [high] VMRs are given in blue [red]. White lines indicate PV contours. Eureka is indicated by the black circle.

(not shown here) indicates that the FrIAC has weakened but has not tilted during this period. Low ozone VMRs (Fig. 3c) are first observed at $\sim 1400 \mathrm{~K}$ on 6 April and are centered at $\sim 1150 \mathrm{~K}$ on 12 April, $\sim 850 \mathrm{~K}$ on $22 \mathrm{April}$, and $\sim 700 \mathrm{~K}$ on 7 May. The low ozone VMRs above Eureka coincide with the periodicity and altitude range of the low EqLs and enhanced $\mathrm{N}_{2} \mathrm{O}$ (Fig. 3b), suggesting that ozone loss has occurred within the FrIAC.

$\mathrm{NO}_{\mathrm{x}}$ was enhanced in 2011 compared with previous years (Fig. 2g), suggesting that the observed low ozone VMRs within the FrIAC were caused by homogeneous chemistry. Furthermore, SZAs above Eureka range from $\sim 75-95^{\circ}$ on 1 April to $\sim 60-80^{\circ}$ on 31 May and are therefore frequently within the $80-95^{\circ} \mathrm{SZA}$ range for which catalytic ozone destruction cycles (dominated by $\mathrm{NO}_{\mathrm{x}}$ ) lead to maximum ozone loss (Sinnhuber et al., 1999). Ozone loss due to $\mathrm{NO}_{\mathrm{x}}$ chemistry above Eureka was calculated between 1 April and 31 May for 2004-2011, using GMI monthly average $\mathrm{O}_{x}$ loss rates due to $\mathrm{NO}_{2}+\mathrm{O} \rightarrow \mathrm{NO}+\mathrm{O}_{2}$. Note that these average loss rates include processes inside the polar vortex in early April, as well as periods during which the FrIAC was above Eureka. $\mathrm{NO}_{\mathrm{x}}$-driven ozone loss above Eureka was larger in 2011 than in any previous year from the tropopause to $18 \mathrm{hPa}(\sim 700 \mathrm{~K})$ and above $6.9 \mathrm{hPa}(\sim 1000 \mathrm{~K})$.

Below the FrIAC, at $600 \mathrm{~K}$, low ozone (Fig. 3c) also coincides with low EqLs (Fig. 3b), suggesting that ozone loss within transported air masses also occurred at these altitudes. Ozone loss due to $\mathrm{NO}_{\mathrm{x}}$ chemistry calculated in GMI above Eureka at $37 \mathrm{hPa}(\sim 600 \mathrm{~K})$ was 1.2 parts per million by volume (ppmv) for 1 April to 31 May 2011, compared with 0.70.9 ppmv in 2004-2010. Ozone loss at $600 \mathrm{~K}$ was also esti-
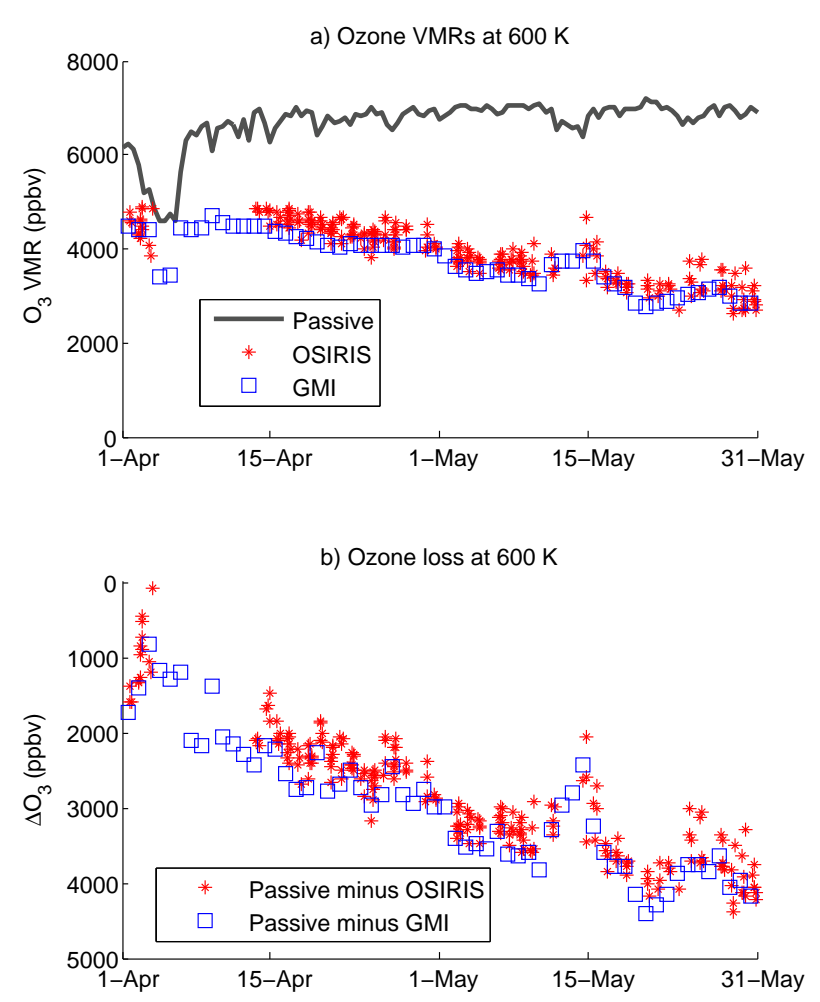

Fig. 8. (a) 2011 ozone VMRs (ppbv) at the $600-\mathrm{K}$ potential temperature level from ATLAS passive ozone above Eureka (black line), OSIRIS ozone within $500 \mathrm{~km}$ of Eureka (red stars), and GMI ozone above Eureka (blue squares). (b) Ozone loss (ppbv) calculated for ATLAS passive ozone minus OSIRIS (red stars) and ATLAS passive ozone minus GMI (blue squares).

mated using the passive tracer technique (e.g., Manney et al., 1995b; WMO, 2003; Konopka et al., 2007) with ATLAS passive ozone, which was initialized on 1 December 2010 with MLS ozone data. Unlike the loss rates calculated with GMI, which are averaged over a particular latitude/longitude, the passive subtraction method estimates the ozone loss within a given air mass throughout its average trajectory since 1 December 2010. Therefore, it captures the ozone loss that occurs as lower-latitude air is transported toward Eureka (see Fig. 6).

Figure 8a shows the 2011 timeseries of ozone VMRs at $600 \mathrm{~K}$ from ATLAS passive ozone, OSIRIS, and GMI. Good agreement is observed between OSIRIS and GMI. The low ozone VMRs in early April coincide with the vortex passing above Eureka. The timeseries of ATLAS passive ozone minus OSIRIS and GMI ozone at $600 \mathrm{~K}$ is shown in Fig. 8 b. Prior to 15 April, much of the variability in ozone loss can be attributed to transport, as the polar vortex passes briefly over Eureka and an anticyclone moves overhead (see Sect. 3.2). On 15 April 2010, an ozone loss of $\sim 2$ ppmv is calculated. This is likely due to $\mathrm{NO}_{\mathrm{x}}$ chemical cycling since 1 December 2010, as low EqL values (see Fig. 3b) suggest that the 


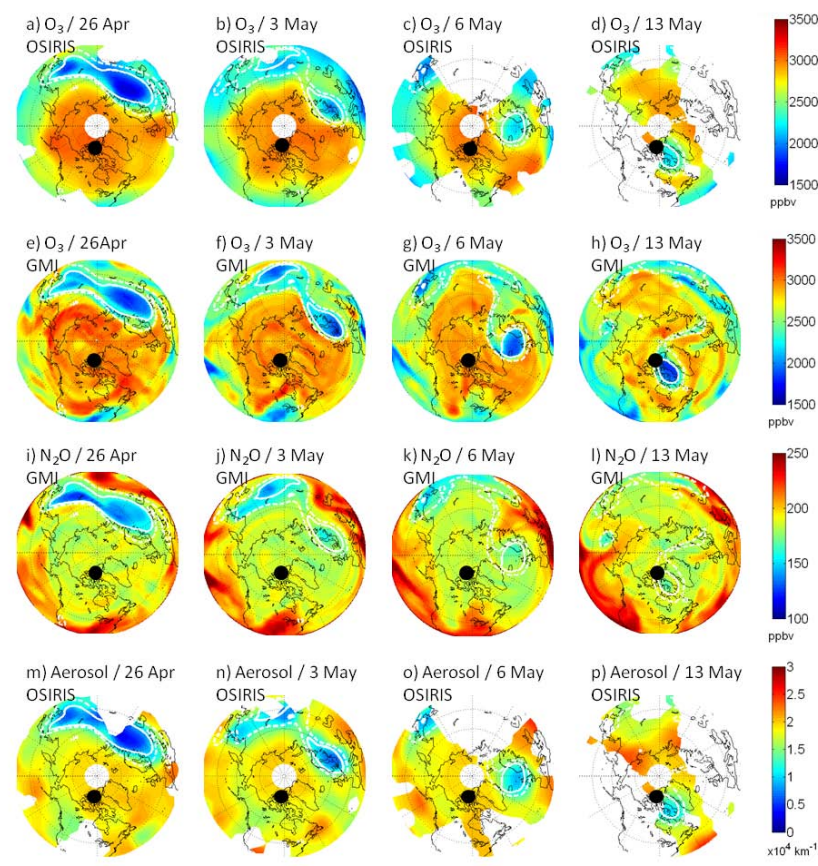

Fig. 9. Polar maps at the $500-\mathrm{K}(\sim 18 \mathrm{~km})$ potential temperature level of OSIRIS ozone VMR in ppbv (top row), GMI ozone VMR in ppbv (top middle row), GMI $\mathrm{N}_{2} \mathrm{O}$ VMR in ppbv (bottom middle row), and OSIRIS aerosol extinction at $750 \mathrm{~nm}$ in $10^{4} \mathrm{~km}^{-1}$ (bottom row) for 26 April and 3, 6, 13 May 2011. Low [high] VMRs and aerosol extinctions are given in blue [red]. The white dashed lines indicate $\mathrm{sPV}=1.2 \times 10^{-4} \mathrm{~s}^{-1}$ (the approximate outer vortex edge) and the thick white lines indicate $\mathrm{SPV}=1.6 \times 10^{-4} \mathrm{~s}^{-1}$ (the approximate inner vortex edge). Eureka is indicated by the black circle.

air mass at $600 \mathrm{~K}$ originates from lower latitudes. Around 12/13 May an isolated vortex air mass passes over Eureka (see Sect. 3.4). Ozone loss within this air mass is reduced, likely because it is poor in $\mathrm{NO}_{\mathrm{x}}$ compared with surrounding air masses. The maximum ozone loss at $600 \mathrm{~K}$ since 1 December 2010 is observed on 20 May 2011 at $4.4 \mathrm{ppmv}$ (61\%) for GMI and $4.2 \mathrm{ppmv}(58 \%)$ for OSIRIS. Ozone losses of $\sim 3$ ppmv between 1 December 2010 and 1 May 2011 are comparable to the losses observed by Konopka et al. (2007) at $600 \mathrm{~K}$ between 1 December 2002 and 1 May 2003. Konopka et al. (2007) attributed this ozone loss to transport of $\mathrm{NO}_{\mathrm{x}}$ during several stratospheric warmings earlier in the year.

\subsection{Other phenomena affecting ozone columns above Eureka}

Ozone and $\mathrm{NO}_{2}$ columns decreased on 12/13 May (Fig. 1, event B). These low columns coincided with high EqLs, low temperatures, and low ozone VMRs at $\sim 500 \mathrm{~K}$ (Fig. 3). Figure 9 shows the evolution of this event at $500 \mathrm{~K}$ in OSIRIS ozone and aerosol and GMI ozone and $\mathrm{N}_{2} \mathrm{O}$. Good agreement
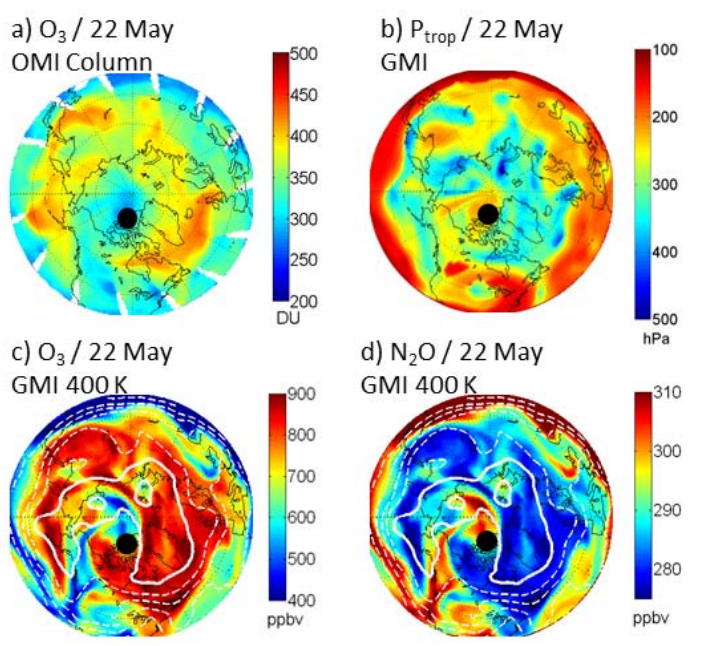

Fig. 10. Formation of ozone mini-hole above Eureka: (a) OMI ozone total columns (DU), (b) GMI tropopause pressure (hPa), (c) GMI ozone VMR at $400 \mathrm{~K}$, and (d) GMI $\mathrm{N}_{2} \mathrm{O}$ VMR at $400 \mathrm{~K}$ $(\sim 13 \mathrm{~km})$. For ozone and $\mathrm{N}_{2} \mathrm{O}$, low [high] VMRs are given in blue [red]. The color scale for the tropopause pressure is reversed so that low pressures (high altitudes) are in red and high pressures (low altitudes) are in blue. The white contour lines indicate the geopotential height, with thick lines indicating 13.4 and $13.6 \mathrm{~km}$ and thin dashed lines indicating $>13.6 \mathrm{~km}$ on $0.2-\mathrm{km}$ intervals. Eureka is indicated by the black circle.

is observed between GMI and OSIRIS ozone. The approximate outer vortex edge $\left(\mathrm{sPV}=1.2 \times 10^{-4} \mathrm{~s}^{-1}\right.$, dashed white lines) and inner vortex edge (sPV $=1.6 \times 10^{-4} \mathrm{~s}^{-1}$, thick white lines) are also indicated. Low ozone, $\mathrm{N}_{2} \mathrm{O}$, and aerosol are enclosed within the vortex across the pole from Eureka on 26 April. This air mass is stretched and a vortex remnant moves over Northern Europe in early May. On 13 May, the vortex remnant passes over Eureka, leading to the low ozone column measurements. This is consistent with other studies that have observed confined fragments of vortex air during and following the spring stratospheric final warming (e.g., Hess, 1991).

Minimum ozone columns of 294 DU, $283 \mathrm{DU}$, and $311 \mathrm{DU}$ are observed above Eureka in the GBS, OMI and GMI datasets around 22/23 May 2011 (Fig. 1b, d, e, event C). Figure 10 shows the evolution of this event. On 22 May, a large pocket of low ozone $(<300 \mathrm{DU})$ is observed in OMI total column data over the pole and Ellesmere Island (panel a). This coincides with low GMI ozone VMRs (panel c) and high GMI $\mathrm{N}_{2} \mathrm{O}$ VMRs (panel d) at $400 \mathrm{~K}$. Equivalent latitudes are $<50^{\circ}$ above Eureka (not shown here) for $350-700 \mathrm{~K}$ on 22 May. This suggests that ozone-poor lowerlatitude air has been transported above Eureka. Geopotential heights at $400 \mathrm{~K}$ (white contours, panels c, d) indicate that the isentropes around the mini-hole region are raised. The tropopause (panel b) is also elevated. This suggests that more ozone-poor tropospheric air is contributing to the total 
column. This is consistent with the formation of an ozone mini-hole, which can lead to large decreases in the ozone column over a short time period (e.g. Peters et al., 1995; James, 1998; Hood et al., 2001; Iwao and Hirooka, 2006). Ozone mini-holes are caused by dynamical processes (e.g., Hood et al., 2001), usually resulting from a combination of the transport of lower-latitude ozone-poor air masses and a rise in the tropopause, as shown on 22 May 2011 above Eureka.

\section{Conclusions}

The evolution of ozone and $\mathrm{NO}_{2}$ was observed above Eureka $\left(80.05^{\circ} \mathrm{N}, 86.42^{\circ} \mathrm{W}\right)$ during and after the final warming of the record-strong polar vortex in spring 2011. Good qualitative agreement was observed between ground-based DOAS, OMI and OSIRIS satellite, and GMI model ozone and $\mathrm{NO}_{2}$ during this period.

As the vortex moved away from Eureka on 8 April 2011, $\mathrm{NO}_{2}$ columns were nearly twice as large as in previous years during the same period. This coincided with high temperatures and large ozone VMRs, suggesting chemical production of $\mathrm{NO}_{2}$. Furthermore, GMI $\mathrm{NO}_{\mathrm{x}}$ and $\mathrm{N}_{2} \mathrm{O}$ fields suggest that at $600 \mathrm{~K}$, near the $\mathrm{NO}_{2}$ maximum, $\mathrm{NO}_{\mathrm{x}}$ descended from higher altitudes along the vortex edge and became trapped above Eureka between a lower-latitude air mass and the vortex. Above the $\mathrm{NO}_{2}$ maximum, $\mathrm{NO}_{\mathrm{x}}$-rich air was transported over Eureka from low-latitudes into an anticyclone. This anticyclone became frozen-in and persisted until the end of the measurement period on 31 May 2011.

Ozone was trapped at high latitudes and depleted by the enhanced $\mathrm{NO}_{\mathrm{x}}$. GMI ozone loss due to $\mathrm{NO}_{\mathrm{x}}$ above Eureka for 1 April to 31 May was larger in 2011 than for any other year in the dataset (2004-2010) for most of the stratosphere, including the region containing the bulk of the ozone column, from the tropopause to $18 \mathrm{hPa}(\sim 700 \mathrm{~K})$ and above $6.9 \mathrm{hPa}(\sim 1000 \mathrm{~K})$. Chemical ozone loss since 1 December 2010 within the air mass that was above Eureka on 20 May 2011 was calculated using ATLAS passive ozone, and reached $4.4 \mathrm{ppmv}(61 \%)$ in GMI data and $4.2 \mathrm{ppmv}(58 \%)$ in OSIRIS data at $600 \mathrm{~K}$. For $\sim 700-1400 \mathrm{~K}$, ozone loss occurred within a FrIAC, which persisted until at least the end of May.

On 12/13 May, a vortex remnant at $\sim 500 \mathrm{~K}$ passed over Eureka, leading to a reduction in the ozone columns. Low ozone columns were also observed on 22/23 May and were consistent with the formation of an ozone mini-hole due to horizontal transport of lower-latitude ozone-poor air and a rise in the tropopause height.

The dynamical variability in the Arctic stratosphere appears to be increasing, with warm winters getting warmer and cold winters getting colder: the four warmest and the two coldest winters since the 1970s have occurred within the last decade (e.g., Manney et al., 2011). Substantial transport of lower-latitude $\mathrm{NO}_{\mathrm{x}}$ and subsequent middle stratospheric ozone loss via gas-phase chemistry was previously observed in spring 2003, following a warm winter that was perturbed by a minor stratospheric warming in December and a major warming in January (Konopka et al., 2007). In the present study, similar middle-stratospheric ozone losses were observed during the break-up of the record-strength vortex in April/May 2011, indicating that significant $\mathrm{NO}_{\mathrm{x}}$ transport and subsequent ozone loss can also follow an unusually cold, dynamically quiescent winter.

Acknowledgements. The 2006-2011 UT-GBS, PEARL-GBS, SAOZ, and Bruker FTIR measurements at Eureka were made at PEARL by CANDAC. CANDAC is supported by the Atlantic Innovation Fund/Nova Scotia Research Innovation Trust, Canada Foundation for Innovation, Canadian Foundation for Climate and Atmospheric Sciences, Canadian Space Agency (CSA), Environment Canada (EC), Government of Canada International Polar Year funding, Natural Sciences and Engineering Research Council (NSERC), Northern Scientific Training Program (NSTP), Ontario Innovation Trust, Polar Continental Shelf Program, and Ontario Research and Development Challenge Fund. Brewer and ozonesonde measurements were made by EC. The spring 20042011 GBS measurements were also supported by the Canadian Arctic ACE Validation Campaigns, which were funded by CSA, NSERC, NSTP, and EC. Spring 2007 GBS measurements were also supported by the Centre for Global Change Science. The 2003 GBS measurements were supported by CFCAS and NSTP. C. Adams was partially supported by the NSERC CREATE Training Program in Arctic Atmospheric Science. The authors wish to thank PEARL site manager Pierre F. Fogal, the CANDAC operators, and the staff at EC's Eureka weather station for their contributions to data acquisition, and logistical and on-site support. The QDOAS software and AMFs were provided by C. Fayt, F. Hendrick, and M. Van Roozendael at IASB-BIRA. Odin is a Swedish-led satellite project funded jointly by Sweden (SNSB), the CSA, Finland (TEKES), France (CNES), and supported since 2007 by the third party mission programme of the European Space Agency. We acknowledge the free use of ozone and $\mathrm{NO}_{2}$ columns data from the OMI sensor from www.temis.nl. Thank-you to Folkert Boersma for advice regarding the use of $\mathrm{OMI} \mathrm{NO}_{2}$ datasets. Work carried out at the Jet Propulsion Laboratory, California Institute of Technology was done under contract with the National Aeronautics and Space Administration. The authors wish to thank Ashley Jones and Thomas Walker for advice on treatment and presentation of satellite datasets. Thank-you also to Dylan Jones for the discussions regarding chemical tracers and to Chris Meek for discussions about anticyclones.

Edited by: W. Lahoz 


\section{References}

Adams, C., Strong, K., Batchelor, R. L., Bernath, P. F., Brohede, S., Boone, C., Degenstein, D., Daffer, W. H., Drummond, J. R., Fogal, P. F., Farahani, E., Fayt, C., Fraser, A., Goutail, F., Hendrick, F., Kolonjari, F., Lindenmaier, R., Manney, G., McElroy, C. T., McLinden, C. A., Mendonca, J., Park, J.-H., Pavlovic, B., Pazmino, A., Roth, C., Savastiouk, V., Walker, K. A., Weaver, D., and Zhao, X.: Validation of ACE and OSIRIS ozone and NO2 measurements using ground-based instruments at $80^{\circ} \mathrm{N}$, Atmos. Meas. Tech., 5, 927-953, doi:10.5194/amt-5-927-2012, 2012a.

Adams, C., Strong, K., Zhao, X., Bassford, M. R., Chipperfield, M. P., Daffer, W., Drummond, J. R., Farahani, E. E., Feng, W., Fraser, A., Goutail, F., Manney, G., McLinden, C. A., Pazmino, A., Rex, M., and Walker, K. A.: Severe 2011 ozone depletion assessed with 11 years of ozone, $\mathrm{NO}_{2}$, and OClO measurements at $80^{\circ} \mathrm{N}$, Geophys. Res. Lett., 39, L05806, doi:10.1029/2011GL050478, 2012b.

Allen, D., Pickering, K., Duncan, B., and Damon, M.: Impact of lightning NO emissions on North American photochemistry as determined using the Global Modeling Initiative (GMI) model, J. Geophys. Res., 115, D22301, doi:10.1029/2010JD014062, 2010.

Allen, D. R., Douglass, A. R., Manney, G. L., Strahan, S. E., Krosschell, J. C., Trueblood, J. V., Nielsen, J. E., Pawson, S., and Zhu, Z.: Modeling the Frozen-In Anticyclone in the 2005 Arctic Summer Stratosphere, Atmos. Chem. Phys., 11, 4557-4576, doi:10.5194/acp-11-4557-2011, 2011.

Balis, D., Isaksen, I. S. A., Zerefos, C., Zyrichidou, I., Eleftheratos, K., Tourpali, K., Bojkov, R., Rognerud, B., Stordal, F., Sovde, O. A., and Orsolini, Y.: Observed and modelled record ozone decline over the Arctic during winter/spring 2011, Geophys. Res. Lett., 38, L23801, doi:10.1029/2011GL049259, 2011.

Boersma, K. F., Eskes, H. J., Veefkind, J. P., Brinksma, E. J., van der A, R. J., Sneep, M., van den Oord, G. H. J., Levelt, P. F., Stammes, P., Gleason, J. F., and Bucsela, E. J.: Near-real time retrieval of tropospheric $\mathrm{NO}_{2}$ from OMI, Atmos. Chem. Phys., 7, 2103-2118, doi:10.5194/acp-7-2103-2007, 2007.

Boersma, K. F., Braak, R., and Van Der A, R.: Dutch OMI $\mathrm{NO}_{2}$ (DOMINO) data product v2.0: http://www.temis.nl/docs/OMI_ NO2_HE5_2.0_2011.pdf (last access: 13 January 2012), 2011.

Bogumil, K., Orphal, J., Homann, T., Voigt, S., Spietz, P., Fleischmann, O. C., Vogel, A., Hartmann, M., Kromminga, H., Bovensmann, H., Frerick, J., and Burrows, J. P.: Measurements of molecular absorption spectra with the SCIAMACHY preflight model: instrument characterization and reference data for atmospheric remote-sensing in the $230-2380 \mathrm{~nm}$ region, J. Photoch. Photobio. A, 157, 167-184, doi:10.1016/S10106030(03)00062-5, 2003.

Bourassa, A. E., Degenstein, D. A., Gattinger, R. L., and Llewellyn, E. J.: Stratospheric aerosol retrieval with optical spectrograph and infrared imaging system limb scatter measurements, J. Geophys. Res., 112, D10217, doi:10.1029/2006JD008079, 2007.

Bourassa, A. E., Rieger, L. A., Lloyd, N. D., and Degenstein, D. A.: Odin-OSIRIS stratospheric aerosol data product and SAGE III intercomparison, Atmos. Chem. Phys., 12, 605-614, doi:10.5194/acp-12-605-2012, 2012.

Brohede, S., McLinden, C. A., Urban, J., Haley, C. S., Jonsson, A. I., and Murtagh, D.: Odin stratospheric proxy $\mathrm{NO}_{\mathrm{y}}$ measurements and climatology, Atmos. Chem. Phys., 8, 5731-5754, doi:10.5194/acp-8-5731-2008, 2008.
Butchart, N. and Remsberg, E. E.: The Area of the Stratospheric Polar Vortex as a Diagnostic for Tracer Transport on an Isentropic Surface, J. Atmos. Sci., 43, 1319-1339, 1986.

Chance, K. V. and Spurr, R. J. D.: Ring effect studies: Rayleigh scattering, including molecular parameters for rotational Raman scattering, and the Fraunhofer spectrum, Appl. Opt., 36, 52245230, 1997.

Dee, D. P., Uppala, S. M., Simmons, A. J., Berrisford, P., Poli, P., Kobayashi, S., Andrae, U., Balmaseda, M. A., Balsamo, G., Bauer, P., Bechtold, P., Beljaars, A. C. M., van de Berg, L., Bidlot, J., Bormann, N., Delsol, C., Dragani, R., Fuentes, M., Geer, A. J., Haimberger, L., Healy, S. B., Hersbach, H., Holm, E. V., Isaksen, L., Kallberg, P., Koehler, M., Matricardi, M., McNally, A. P., Monge-Sanz, B. M., Morcrette, J. J., Park, B. K., Peubey, C., de Rosnay, P., Tavolato, C., Thepaut, J. N., and Vitart, F.: The ERA-Interim reanalysis: configuration and performance of the data assimilation system, Q. J. Roy. Meteor. Soc., 137, 553-597, 2011.

Degenstein, D. A., Bourassa, A. E., Roth, C. Z., and Llewellyn, E. J.: Limb scatter ozone retrieval from 10 to $60 \mathrm{~km}$ using a multiplicative algebraic reconstruction technique, Atmos. Chem. Phys., 9, 6521-6529, doi:10.5194/acp-9-6521-2009, 2009.

Dirksen, R. J., Boersma, K. F., Eskes, H. J., Ionov, D. V., Bucsela, E. J., Levelt, P. F., and Kelder, H. M.: Evaluation of stratospheric $\mathrm{NO}_{2}$ retrieved from the Ozone Monitoring Instrument: Intercomparison, diurnal cycle, and trending, J. Geophys. Res., 116, D08305, doi:10.1029/2010JD014943, 2011.

Duncan, B. N., Strahan, S. E., Yoshida, Y., Steenrod, S. D., and Livesey, N.: Model study of the cross-tropopause transport of biomass burning pollution, Atmos. Chem. Phys., 7, 3713-3736, doi:10.5194/acp-7-3713-2007, 2007.

Dunkerton, T. J. and Delisi, D. P.: Evolution of Potential Vorticity in the Winter Stratosphere of January February 1979, J. Geophys. Res., 91, 1199-1208, 1986.

Fahey, D. W. and Ravishankara, A. R.: Summer in the stratosphere, Science, 285, 208-210, 1999.

Farman, J. C., Murgatroyd, R. J., Silnickas, A. M., and Thrush, B. A.: Ozone Photochemistry in the Antarctic Stratosphere in Summer, Q. J. Roy. Meteor. Soc., 111, 1013-1025, 1985.

Fayt, C., De Smedt, I., Letocart, V., Merlaud, A., Pinardi, G., and Van Roozendael, M.: QDOAS Software user manual version 1.00: http://uv-vis.aeronomie.be/software/QDOAS/index. php (last access: 15 February 2012), 2011.

Fleischmann, O. C., Hartmann, M., Burrows, J. P., and Orphal, J.: New ultraviolet absorption cross-sections of $\mathrm{BrO}$ at atmospheric temperatures measured by time-windowing Fourier transform spectroscopy, J. Photoch. Photobio. A, 168, 117-132, 2004.

Fraser, A., Goutail, F., Strong, K., Bernath, P. F., Boone, C., Daffer, W. H., Drummond, J. R., Dufour, D. G., Kerzenmacher, T. E., Manney, G. L., McElroy, C. T., Midwinter, C., McLinden, C. A., Nichitiu, F., Nowlan, C. R., Walker, J., Walker, K. A., $\mathrm{Wu}, \mathrm{H}$., and Zou, J.: Intercomparison of UV-visible measurements of ozone and $\mathrm{NO}_{2}$ during the Canadian Arctic ACE validation campaigns: 2004-2006, Atmos. Chem. Phys., 8, 1763-1788, doi:10.5194/acp-8-1763-2008, 2008.

Fraser, A., Adams, C., Drummond, J. R., Goutail, F., Manney, G., and Strong, K.: The Polar Environment Atmospheric Research Laboratory UV-visible ground-based spectrometer: first measurements of $\mathrm{O}_{3}, \mathrm{NO}_{2}, \mathrm{BrO}$, and $\mathrm{OClO}$ columns, J. Quant. 
Spectrosc. Ra., 110, 986-1004, doi:10.1016/j.jqsrt.2009.02.034, 2009.

Greenblatt, G. D., Orlando, J. J., Burkholder, J. B., and Ravishankara, A. R.: Absorption-measurements of oxygen between $330 \mathrm{~nm}$ and $1140 \mathrm{~nm}$, J. Geophys. Res., 95, 18577-18582, 1990.

Harvey, V. L., Hitchman, M. H., Pierce, R. B., and Fairlie, T. D.: Tropical aerosol in the Aleutian High, J. Geophys. Res., 104, 6281-6290, 1999.

Harvey, V. L., Pierce, R. B., Fairlie, T. D., and Hitchman, M. H.: A climatology of stratospheric polar vortices and anticyclones, J. Geophys. Res., 107, 4442, doi:10.1029/2001JD001471, 2002.

Harvey, V. L., Pierce, R. B., Hitchman, M. H., Randall, C. E., and Fairlie, T. D.: On the distribution of ozone in stratospheric anticyclones, J. Geophys. Res., 109, D24308, doi:10.1029/2004JD004992, 2004.

Harvey, V. L., Randall, C. E., Manney, G. L., and Singleton, C. S.: Low-ozone pockets observed by EOS-MLS, J. Geophys. Res., 113, D17112, doi:10.1029/2007JD009181, 2008.

Hendrick, F., Pommereau, J.-P., Goutail, F., Evans, R. D., Ionov, D., Pazmino, A., Kyrö, E., Held, G., Eriksen, P., Dorokhov, V., Gil, M., and Van Roozendael, M.: NDACC/SAOZ UV-visible total ozone measurements: improved retrieval and comparison with correlative ground-based and satellite observations, Atmos. Chem. Phys., 11, 5975-5995, doi:10.5194/acp-11-5975-2011, 2011.

Hess, P. G.: Mixing Processes Following the Final Stratospheric Warming, J. Atmos. Sci., 48, 1625-1641, 1991.

Hood, L. L., Soukharev, B. E., Fromm, M., and McCormack, J. P.: Origin of extreme ozone minima at middle to high northern latitudes, J. Geophys. Res., 106, 20925-20940, 2001.

Iwao, K. and Hirooka, T.: Dynamical quantifications of ozone minihole formation in both hemispheres, J. Geophys. Res., 111, D02104, doi:10.1029/2005JD006333, 2006.

James, P. M.: A climatology of ozone mini-holes over the northern hemisphere, Int. J. Climatol., 18, 1287-1303, 1998.

Kerzenmacher, T. E., Walker, K. A., Strong, K., Berman, R., Bernath, P. F., Boone, C. D., Drummond, J. R., Fast, H., Fraser, A., MacQuarrie, K., Midwinter, C., Sung, K., McElroy, C. T., Mittermeier, R. L., Walker, J., and Wu, H. J.: Measurements of $\mathrm{O}_{3}, \mathrm{NO}_{2}$ and temperature during the 2004 Canadian Arctic ACE Validation Campaign, Geophys. Res. Lett., 32, L16S07, doi:10.1029/2005GL023032, 2005.

Konopka, P., Engel, A., Funke, B., Mueller, R., Grooss, J.U., Guenther, G., Wetter, T., Stiller, G., von Clarmann, T., Glatthor, N., Oelhaf, H., Wetzel, G., Lopez-Puertas, M., Pirre, M., Huret, N., and Riese, M.: Ozone loss driven by nitrogen oxides and triggered by stratospheric warmings can outweigh the effect of halogens, J. Geophys. Res., 112, D05105, doi:10.1029/2006JD007064, 2007.

Lahoz, W. A., Geer, A. J., and Orsolini, Y. J.: Northern Hemisphere stratospheric summer from MIPAS observations, Q. J. Roy. Meteor. Soc., 133, 197-211, 2007.

Levelt, P. F., Van den Oord, G. H. J., Dobber, M. R., Malkki, A., Visser, H., de Vries, J., Stammes, P., Lundell, J. O. V., and Saari, H.: The Ozone Monitoring Instrument, IEEE T. Geosci. Remote, 44, 1093-1101, 2006.

Lindenmaier, R., Strong, K., Batchelor, R. L., Chipperfield, M. P., Daffer, W. H., Drummond, J. R., Duck, T. J., Fast, H., Feng, W., Fogal, P. F., Kolonjari, F., Manney, G. L., Manson, A., Meek,
C., Mittermeier, R. L., Nott, G. J., Perro, C., and Walker, K. A.: Unusually low ozone, $\mathrm{HCl}$, and $\mathrm{HNO}_{3}$ column measurements at Eureka, Canada during winter/spring 2011, Atmos. Chem. Phys., 12, 3821-3835, doi:10.5194/acp-12-3821-2012, 2012.

Llewellyn, E., Lloyd, N. D., Degenstein, D. A., Gattinger, R. L., Petelina, S. V., Bourassa, A. E., Wiensz, J. T., Ivanov, E. V., McDade, I. C., Solheim, B. H., McConnell, J. C., Haley, C. S., von Savigny, C., Sioris, C. E., McLinden, C. A., Griffioen, E., Kaminski, J., Evans, W. F. J., Puckrin, E., Strong, K., Wehrle, V., Hum, R. H., Kendall, D. J. W., Matsushita, J., Murtagh, D. P., Brohede, S., Stegman, J., Witt, G., Barnes, G., Payne, W. F., Piche, L., Smith, K., Warshaw, G., Deslauniers, D. L., Marchand, P., Richardson, E. H., King, R. A., Wevers, I., McCreath, W., Kyrola, E., Oikarinen, L., Leppelmeier, G. W., Auvinen, H., Megie, G., Hauchecorne, A., Lefevre, F., de La Noe, J., Ricaud, P., Frisk, U., Sjoberg, F., von Scheele, F., and Nordh, L.: The OSIRIS instrument on the Odin spacecraft, Can. J. Phys., 82, 411-422, 2004.

Manney, G. L., Zurek, R. W., Oneill, A., and Swinbank, R.: On The Motion of Air Through the Stratospheric Polar Vortex, J. Atmos. Sci., 51, 2973-2994, 1994.

Manney, G. L., Froidevaux, L., Waters, J. W., Zurek, R. W., Gille, J. C., Kumer, J. B., Mergenthaler, J. L., Roche, A. E., Oneill, A., and Swinbank, R.: Formation Of Low-Ozone Pockets In The Middle Stratospheric Anticyclone During Winter, J. Geophys. Res., 100, 13939-13950, 1995a.

Manney, G. L., Zurek, R. W., Froidevaux, L., Waters, J. W., Oneill, A., and Swinbank, R.: Lagrangian Transport Calculations Using UARS Data. 2. Ozone, J. Atmos. Sci., 52, 3069-3081, 1995 b.

Manney, G. L., Livesey, N. J., Jimenez, C. J., Pumphrey, H. C., Santee, M. L., MacKenzie, I. A., and Waters, J. W.: EOS Microwave Limb Sounder observations of "frozen-in" anticyclonic air in arctic summer, Geophys. Res. Lett., 33, L06810, doi:10.1029/2005GL025418, 2006.

Manney, G. L., Daffer, W. H., Zawodny, J. M., Bernath, P. F., Hoppel, K. W., Walker, K. A., Knosp, B. W., Boone, C., Remsberg, E. E., Santee, M. L., Harvey, V. L., Pawson, S., Jackson, D. R., Deaver, L., McElroy, C. T., McLinden, C. A., Drummond, J. R., Pumphrey, H. C., Lambert, A., Schwartz, M. J., Froidevaux, L., McLeod, S., Takacs, L. L., Suarez, M. J., Trepte, C. R., Cuddy, D. C., Livesey, N. J., Harwood, R. S., and Waters, J. W.: Solar occultation satellite data and derived meteorological products: Sampling issues and comparisons with Aura Microwave Limb Sounder, J. Geophys. Res., 112, D24S50, doi:10.1029/2007JD008709, 2007.

Manney, G. L., Santee, M. L., Rex, M., Livesey, N. J., Pitts, M. C., Veefkind, P., Nash, E. R., Wohltmann, I., Lehmann, R., Froidevaux, L., Poole, L. R., Schoeberl, M. R., Haffner, D. P., Davies, J., Dorokhov, V., Gernandt, H., Johnson, B., Kivi, R., Kyro, E., Larsen, N., Levelt, P. F., Makshtas, A., McElroy, C. T., Nakajima, H., Parrondo, M. C., Tarasick, D. W., von der Gathen, P., Walker, K. A., and Zinoviev, N. S.: Unprecedented Arctic ozone loss in 2011, Nature, 478, 469-475, doi:10.1038/nature10556, 2011.

McPeters, R., Kroon, M., Labow, G., Brinksma, E., Balis, D., Petropavlovskikh, I., Veefkind, J. P., Bhartia, P. K., and Levelt, P. F.: Validation of the Aura Ozone Monitoring Instrument total column ozone product, J. Geophys. Res., 113, D15S14, doi:10.1029/2007JD008802, 2008. 
Morris, G. A., Kawa, S. R., Douglass, A. R., Schoeberl, M. R., Froidevaux, L., and Waters, J.: Low-ozone pockets explained, J. Geophys. Res., 103, 3599-3610, 1998.

Murtagh, D., Frisk, U., Merino, F., Ridal, M., Jonsson, A., Stegman, J., Witt, G., Eriksson, P., Jimenez, C., Megie, G., de la Noe, J., Ricaud, P., Baron, P., Pardo, J. R., Hauchcorne, A., Llewellyn, E. J., Degenstein, D. A., Gattinger, R. L., Lloyd, N. D., Evans, W. F. J., McDade, I. C., Haley, C. S., Sioris, C., von Savigny, C., Solheim, B. H., McConnell, J. C., Strong, K., Richardson, E. H., Leppelmeier, G. W., Kyrola, E., Auvinen, H., and Oikarinen, L.: An overview of the Odin atmospheric mission, Can. J. Phys., 80, 309-319, 2002.

Nair, H., Allen, M., Froidevaux, L., and Zurek, R. W.: Localized rapid ozone loss in the northern winter stratosphere: An analysis of UARS observations, J. Geophys. Res., 103, 1555-1571, 1998.

Orsolini, Y. J. and Nikulin, G.: A low-ozone episode during the European heatwave of August 2003, Q. J. Roy. Meteor. Soc., 132, 667-680, 2006.

Orsolini, Y. J., Eskes, H., Hansen, G., Hoppe, U. P., Kylling, A., Kyro, E., Notholt, J., Van Der A, R., and Von Der Gathen, P.: Summertime low-ozone episodes at northern high latitudes, Q. J. Roy. Meteor. Soc., 129, 3265-3275, 2003.

OSIRIS: Odin-OSIRIS $\mathrm{NO}_{2}$ data product: http://osirus.usask.ca/ ?q=node $/ 245,2011$.

Perliski, L. M., Solomon, S., and London, J.: On the Interpretation of Seasonal-Variations of Stratospheric Ozone, Planet. Space Sci., 37, 1527-1538, 1989.

Peters, D., Egger, J., and Entzian, G.: Dynamical Aspects of Ozone Mini-Hole Formation, Meteorol. Atmos. Phys., 55, 205-214, 1995.

Reinecker, M. M.: The GEOS-5 data assimilation system - Documentation of versions 5.0.1, and 5.2.0, NASA Tech. Memo., TM-2008-104606, 27, 97, 2008.

Rienecker, M. M., Suarez, M. J., Gelaro, R., Todling, R., Bacmeister, J., Liu, E., Bosilovich, M. G., Schubert, S. D., Takacs, L., Kim, G.-K., Bloom, S., Chen, J., Collins, D., Conaty, A., da Silva, A., Gu, W., Joiner, J., Koster, R. D., Lucchesi, R., Molod, A., Owens, T., Pawson, S., Pegion, P., Redder, C. R., Reichle, R., Robertson, F. R., Ruddick, A. G., Sienkiewicz, M., and Woollen, J.: MERRA: NASA's Modern-Era Retrospective Analysis for Research and Applications, J. Climate, 24, 3624-3628, 2011.

Rothman, L. S., Barbe, A., Benner, D. C., Brown, L. R., CamyPeyret, C., Carleer, M. R., Chance, K., Clerbaux, C., Dana, V., Devi, V. M., Fayt, A., Flaud, J. M., Gamache, R. R., Goldman, A., Jacquemart, D., Jucks, K. W., Lafferty, W. J., Mandin, J. Y., Massie, S. T., Nemtchinov, V., Newnham, D. A., Perrin, A., Rinsland, C. P., Schroeder, J., Smith, K. M., Smith, M. A. H., Tang, K., Toth, R. A., Vander Auwera, J., Varanasi, P., and Yoshino, K.: The HITRAN molecular spectroscopic database: edition of 2000 including updates through 2001, J. Quant. Spectrosc. Ra., 82, 5-44, doi:10.1016/S0022-4073(03)00146-8, 2003.

Ruth, S. L., Remedios, J. J., Lawrence, B. N., and Taylor, F. W.: Measurements of $\mathrm{N}_{2} \mathrm{O}$ by the UARS Improved Stratospheric and Mesospheric Sounder during the Early Northern Winter 1991/92, J. Atmos. Sci., 51, 2818-2833, 1994.
Sander, S. P., Friedl, R. R., Barker, J. R., Golden, D. M., Kurylo, M. J., Wine, P. H., Abbatt, J., Brukholder, J. B., Kolb, C. E., Moortgat, G. K., Huie, R. E., and Orkin, V. L.: Chemical Kinetics and Photochemical Data for Use in Atmospheric Studies Evaluation Number 17, JPL Publication 10-6, Jet Propulsion Laboratory, California Institude of Technology, Pasadena, California, 1-684, 2011.

Sinnhuber, B. M., Muller, R., Langer, J., Bovensmann, H., Eyring, V., Klein, U., Trentmann, J., Burrows, J. P., and Kunzi, K. F.: Interpretation of mid-stratospheric Arctic ozone measurements using a photochemical box-model, J. Atmos. Chem., 34, 281290, 1999.

Strahan, S. E., Duncan, B. N., and Hoor, P.: Observationally derived transport diagnostics for the lowermost stratosphere and their application to the GMI chemistry and transport model, Atmos. Chem. Phys., 7, 2435-2445, doi:10.5194/acp-7-2435-2007, 2007.

Thieblemont, R., Huret, N., Orsolini, Y. J., Hauchecorne, A., and Drouin, M. A.: Frozen-in anticyclones occurring in polar Northern Hemisphere during springtime: Characterization, occurrence and link with quasi-biennial oscillation, J. Geophys. Res., 116, D20110, doi:10.1029/2011JD016042, 2011.

Vandaele, A. C., Hermans, C., Simon, P. C., Carleer, M., Colin, R., Fally, S., Merienne, M. F., Jenouvrier, A., and Coquart, B.: Measurements of the $\mathrm{NO}_{2}$ absorption cross-section from 42000 $\mathrm{cm}^{-1}$ to $10000 \mathrm{~cm}^{-1}(238-1000 \mathrm{~nm})$ at $220 \mathrm{~K}$ and $294 \mathrm{~K}$, J. Quant. Spectrosc. Ra., 59, 171-184, 1998.

Veefkind, P., and Sneep, M.: OMDOA03 README FILE: http://disc.sci.gsfc.nasa.gov/Aura/data-holdings/OMI/ documents/v003/OMDOAO3_README_V003.shtml (last access: 14 January 2012), 2009.

Veefkind, J. P., de Haan, J. R., Brinksma, E. J., Kroon, M., and Levelt, P. F.: Total ozone from the Ozone Monitoring Instrument (OMI) using the DOAS technique, IEEE T. Geosci. Remote, 44, 1239-1244, 2006.

Wahner, A., Tyndall, G. S., and Ravishankara, A. R.: Absorption cross-sections for $\mathrm{OClO}$ as a function of temperature in the wavelength range 240-480 nm, J. Phys. Chem., 91, 2734-2738, 1987.

WMO: Scientific Assessment of Ozone Depletion: 2002, Rep. 50, Global Ozone Research and Monitoring Project, World Meteorological Society, Geneva, Switzerland, 2003.

WMO: Scientific Assessment of Ozone Depletion: 2010, Rep. 52, Global Ozone Research and Monitoring Project, World Meteorological Society, Geneva, Switzerland, 2011.

Wohltmann, I. and Rex, M.: The Lagrangian chemistry and transport model ATLAS: validation of advective transport and mixing, Geosci. Model Dev., 2, 153-173, doi:10.5194/gmd-2-153-2009, 2009.

Wohltmann, I., Lehmann, R., and Rex, M.: The Lagrangian chemistry and transport model ATLAS: simulation and validation of stratospheric chemistry and ozone loss in the winter 1999/2000, Geosci. Model Dev., 3, 585-601, doi:10.5194/gmd-3-585-2010, 2010. 